\title{
Abstracts of the ASHS Southern Region 52nd Annual Meeting
}

\section{National Sweetpotato Collaborators}

EFFECT OF PLANT SEACING ON YIELD OF SELECTED SWEET POTATO CULTIVARS WITH VARIOUS PLANTING DATES. W.A. Mulkey* and W.B. McLemore III, LSU Agricultural Center, La. Agricultural Experiment Station, Sweet Potato Research Station, Chase, LA 71324 Three sweet potato cultivars, 'Beauregard', 'Hernandez' and 'Jewel' were transplanted at three different planting dates: June 4, June 21 and July 10 , with harvest at 106,109 and 117 days; respectively. Four in-row spacings of $22.9,30.5,38.1$, and $45.7 \mathrm{~cm}$ on a $1 \mathrm{~mm}$ spacing between rows were used in each of the planting dates. The highest yields of U.S. No.l grade potatoes in the cultivar Beauregard' were produced at the $22.9 \mathrm{~cm}$ spacing in the first two planting dates and at $30.5 \mathrm{~cm}$ in the July 10 planting date. The highest yields of U.S. No.1 grade potatoes in the cultivar 'Hernandez' were produced at $38.1 \mathrm{~cm}$ in all three planting dates. With the cultivar 'Jewel' in the June 4 planting there was only a small difference in yield of U.S. No.1 potatoes at the 22.9, 30.5 and $38.1 \mathrm{~cm}$

spacings. In the June 21 and July 10 plantings the highest $y$ ields were produced at the $22.9 \mathrm{~cm}$ spacing. The $45.7 \mathrm{~cm}$ spacing produced the highest number of marketable roots per hill in all three cultivars.

METHODS TO IMPROVE SWEETPOTATO PLANT PRODUCTION Melvin R. Hall, Department of Horticulture, University of Georgia Coastal Plain Experiment station, Tifton, GA 31793 Most commercial sweetpotato acreage in the United states is grown from plants that have been produced from bedded roots. Development of new methods or new combinations of known methods to increase plant production helps to maximize the number of usable plants produced in a minimum amount of time and also reduces propagation costo while aiding early transplanting. Plant production is influenced greatly by genotype, and many efforts have been directed at improving plant production from aparse plant producing cultivars. Modifications of wounding or cutting treatments, exposure to chemical sprout inducers, presprouting by heat treatments and combinations of these treatments have enhanced plant production from large and small roots of sparse and profuse plant producing cultivars.

EFFECTS OF FIBROUS ROOT INFECTION BY STREPTOMYCES IPOMOEA ON YIELD OF SWEETPOTATO.

Jean B. Ristaino* and Charles Averre, Department of Plant Pathology, North Carolina State University, Raleigh, NC 27695.

The effect of fibrous root infection by $S$. ipomoea on disease on storage roots and production of marketable yield in the susceptible sweetpotato cultivar 'Jcwel' was evaluated in field experiments in 3 years. Drip irrigation (main plots) reduced discase on fibrous roots in plots not treated with sulfur or fumigatcd, but did not significantly increase yields in any year. Sulfur (subplots) reduced the severity of the disease on fibrous roots in nonfumigated plots in 2 years, but reduced yields by $21-33 \%$ in 2 of 3 years. Fumigation of soil with Telone $\mathrm{C}-17$ (sub-subplots) reduced the percentage of diseased storage roots produced per plot from $71 \%, 8 \%$, and $22 \%$ in nonfumigated plots to $52 \%, 3 \%$ and $6 \%$ in fumigated plots in 1988,1989 and 1990 , respectively and reduced the severity of disease on fibrous roots in all years. Only fumigation increased the yield of marketable storage roots by $68 \%$ and $19 \%$ in two of three years. The scverity of disease on fibrous roots was positively correlated with the percentage of discased storage roots produced per plot $(r=0.84)$ and the number of diseased storage roots produced per plant $(r=0.64)$, and was negatively correlated with the number of storage roots produced per plant $(r=-0.66)$. Yield of markctable storage roots was negatively correlated with both the severity of disease on fibrous roots $(r=-0.77)$ and the percentage of diseased storage roots produced per plot $(r=-0.73)$. These data demonstrate the importance of fibrous root disease in this pathosystem. Management strategies that reduce discase on fibrous roots may ultimalely lead to increased yield of storage roots.

SOUTHERN ROOT-KNOT NEMATODE: THE RACE PROBLEM AS RELATED TO BREEDING FOR RESISTANCE IN SWEETPOTATO

P. D. Dukes* and Jantce R. Bohac, U. S. Vegetable Laboratory, ARS, USDA, 2875 Savannah Highway, Charleston, SC 29414-5334

There are four known physiological races of the southern root-knot nematode [Meloldogyne incognita (Kofold \& white)

Chitwood]. Races are designated 1 through 4 and thetr identifications are based solely on differential hosts. These race problems as related to breeding sweetpotato for resistance to attack by all races are reviewed and discussed. Data are presented showing the reactions of selected cultivars and breeding clones of sweetpotato to all four races. The reactions of races 1 and 3 are generally well-known. Races 2 and 4 apparently are spreading and becoming more numerous in the southern states where soybean and tobacco are grown. Comparative disease indices are presented showing that generally sweetpotatoes were less susceptible to races 2 and 4. However, there were some notable exceptions, for example, 'Sulfur' and 'Beauregard' were equally susceptible to all races. High resistances to attack by races 2 and 4 were found in 'Sumor', 'Nemagold', 'Excel', W-241 and others.

\section{J.B. Edmond Undergraduate}


INFLUENCE OF CONTAINER SIZE AND TRANSPLANT SEQUENCE ON ROOT DEVELOPMENT OF TWO ILEX SPECIES

Patricia R. Knight*, D. Joseph Eakes, Kenneth M, Tilt. and Charles H. Gilliam, Department of Horticulture, Auburn University, Auburn University, AL 36849

Stem cuttings of Ilex cornuta 'Burfordi i Nana' and Ilex $x$ 'Nell ie R. Stevens', were direct stuck into cell pack, rose pot, quart pot, and trade gallon containers on March 4, 1991 . Ten weeks and again at twenty weeks after sticking, rooted liners from cell pack, rose pot, and quart pot containers were transplanted into trade gallon containers. Thirty weeks after sticking, Nellie R. Stevens holly had a greater total root dry weight compared to Dwarf Burford holly. There were no differences in total root dry weight for any transplant treatment, but root distribution was influenced. Cell pack and rose pot liners transplanted twenty weeks after sticking showed a reduction in root growth in the root sector between the radius of a quart pot and a trade gallon pot. Shoot growth was also reduced for cell pack and rose pot liners that were transplanted into trade galion containers twenty weeks after sticking.

EVALUATION OF SEVERAL GROWING MEDIA FOR USE IN NITROGEN FIXATION RESEARCH

Stephanie Rademart and Dyremple Marsh, Department of Agriculture, Lincoln University Jefferson City, MO 65101 A wide range of methodologies, ranging from Leonard jar to growth pouch have been used to investigate the nitrogen fixation process in leguminous crops. The effectiveness of most of these research methods have been questioned. Problems encountered vary from difficulty in root separation to water $\log$ conditions. This study was undertaken to determine the effect of different growing media on nodule development and harvestability. Black and Red seed on nodule development and harvestability. Black and Red seed coat kidney bean were surface sterilized and inoculated with
the Rhizobium phaseoli strain UMR 1899 . Seeds were planted in $8.5 \mathrm{~cm}$ diameter sterile clay pots containing the respective growing medium. These growing media were sand, Promix GM, Promix BX, and fritted clay. The black seed coat kidney bean had higher germination rate under all media for all dates recorded. Black kidney bean grown in sand and fritted clay had plant heights significantly greater than ones grown in the other media on the third harvest date. Nodule activities as measured by shoot dry weight and nodule number were significantly higher in both beans grown in fritted clay than in other media. Promix GM plants with grown in fritted clay than in other media. Promix ary weight of $.45 \mathrm{~g}$ for the black bean and $32 \mathrm{~g}$ for the red beans were the lowest. Nodule separation from the growing media was significantly different from that of plants grown in fritted clay.
sition

\section{TISSUE CULTURE OF WETLAND ENDANGERED} PLANT SPECIES.

Robert Price*, and Marihelen Kamp-Glass, David Powell, Department of Plant Science \& Technology, North Carolina Agricultural and Technical State University, Greensboro, NC 27411.

Venus fly trap, Dionaea muscipula Ellis, leaf sections were surfaced sterilized under aseptic conditions. The leaf sections were cultured in reduced strength Muashige and Skoog growth medium supplemented with $2,25 \mathrm{mg} / \mathrm{l}$ 6Benzylaminopurine and $1.0-2.0 \mathrm{mg} / \mathrm{K}$ Kinetin. The various levels of cytokinin were used to differentiate and enhance callus formation.

THE EDUCATIONAL BENEFIT OF TWO DEMONSTRATION XERISCAPE GARDENS

Bobby Mottern* (Mary Haque and Judy Caldwell, Advisors), Department of Horticulture, Clemson University, Clemson, SC 29634-0375

Two xeriscape gardens have been designed for the purpose of educating the public about the importance of water conservation through xeriscaping. One was designed and implemented for a temporary exhibit at the South Carolina State Fair in October of 1991. The exhibit was cosponsored by the Clemson University Extension Service and Master Gardener programs.

The second garden has been designed for the Clemson University Botanical Garden. This will be a permanant addition to the botanical garden soley for display purposes. It is designed to be a model for students, professors, and the general public to observe and study principles associated with water conservation in the landscape.

\section{Anderson Graduate}

GROWTH OF SELECT CONTAINER GROWN FLOWERING DOGWOODS AS INFLUENCED BY PRODUCTION PRACTICES

D. Thayne Montaque*, D. Joseph Eakes, Charles H. Gilli iam, Horticulture, Auburn University, Auburn, AL 36849

This study was conducted to determine the influence of production methods on the growth of container grown flowering dogwood (Cornus florida). The production practices were: ful1 sun, $40 \%$ white shade cloth, $40 \%$ black shade cloth, and pot-in-pot. The cultivars studied were: cv. 'Welch's Junior Miss', cv. 'Barton's White', cv. 'Weaver's White', and cv. 'Welch's Bay Beauty'. The one variety used was pink. Height and caliper data was collected. Plants grown under white shade cloth had the highest overall height and caliper growth, followed by black shade cloth, full sun, and the pot-in-pot production method. The cultivar 'Weaver's White' had the highest overall height and caliper growth and the variety pink had the least, regardless of treatment. The remaining cultivars had similar growth regardless of treatment.

INFLUENCE OF IRON DTPA ON THE OCCURRENCE OF A SPECIFIC PHYSIOLOGICAL DISORDER IN CUTTING GERANIUM.

Gary R. Bachman* and Mary C. Halbrooks. Department of

Horticulture, Clemson University, Clemson, SC 29634-0375.

The role of Fe DTPA (Diethylenetriaminepentaacetic acid) in the occurrence of a specific physiological disorder affecting the leaves of cutting geranium was investigaled. Industry reports indicate that affected leaves have excessively high concentrations of $\mathrm{Fe}$ and sometimes Mn. Symptoms of the disorder first affecl maturing leaves, and may in severe cases affect immature leaves. Symptoms progress from marginalinterveinal chlorosis and necrosis, to affect whole leaf necrosis. Rooted cuttings were grown in a soil-less peat based media, with $\mathrm{Fe}$ DTPA concentrations of $1,5,15$, and $20 \mathrm{ppm}$. Iron and manganese leaf concentrations were significantly higher in symplom than in non-symptom tissue and increased as Fe DTPA treatment level increased. As Fe DTPA treatment level increased there was a significant increase in dry weight of symptom tissue and a decrease in non-symptom tissue dry weight. Plants grown in media amended with dolomite $(\mathrm{pH}>5.8)$ had similar degrees of symplom occurrence compared to plants grown in unamended media $(\mathrm{pH} \approx 5.4)$.

\section{USE OF THE POUR-THROUGH NUTRIENT EXTRACTION PROCEDURE FOR BEDDING FLATS AND PLUG TRAYS}

\section{Amelia L. Schweizer* and Kevin L. Grueber}

Department of Hort., VPI and SU, Blacksburg, VA 24061

A study was conducted to develop and demonstrate a practical and accurate method of applying the Pour-Through nutrient extraction procedure to bedding flats and plug trays. The PourThrough technique involves pouring a known volume of water on previously saturated medium, and collecting the leachate which is pushed out the bottom of the container. The volume of applied water necessary to conduct a bedding flat or plug tray Pour-Through was determined based on leachate $\mathrm{pH}$ and conductivity. The sensitivity of the Pour-Through technique when applied to bedding flats and plug trays was determined using varying rates of lime incorporated media and fertilizer. The leachate was analyzed for $\mathrm{pH}$ and conductivity. Results indicate that the technique can be used effectively on bedding flats and plug trays.

\section{ROOT REGENERATION OF SAWTOOTH OAK AFTER CHEMICAL ROOT PRUNING}

Phillip C. Flanagan*1 and W.T. Witte. Department of Ornamental Horticulture and Landscape Design, University of Tennessee, Knoxville. TN 37901-1071

Previous research at this facility has shown that copper sulfate, when incorporated with latex paint and applied to the interior surfaces of tube trays, was effective in chemically root pruning Quercus acutissima seedlings. Only $20 \%$ of deflected roots continued to grow after contacting $\mathrm{Cu}$ treated tube walls compared to controls. Treated plants showed a reduction of fibrous roots on the plug surface. Height and caliper were not affected by $\mathrm{Cu}$ treatments during chemical root pruning in the tube tray. Time required for regeneration of new roots was not affected by $\mathrm{Cu}$ 
treatments. Seedlings from each treatment were planted and grown two seasons under field conditions to observe effects on growth and root regeneration. No treatment effects occurred for height or caliper. Oak seedlings chemically root pruned with $\mathrm{Cu}$ exhibited more lateral growth and branching than control plants.

'Present address: Research Associate, Tennessee State University - Nursery Crops Research Station, Cadillac Lane, McMinnville, TN 37110

\section{PROPAGATION OF BLACKBERRIES USING VARIOUS ROOTING COMPOUNDS} A.L. Busby*, D.G. Himelrick and D.J. Eakes, Department of Horticulture, Auburn University, Auburn, AL 36849

Two cultivars of blackberry (Rubus sp.) were propagated in July under intermittent mist by rooting 2-node softwood stem cuttings. Differences in root development among cultivars were evident with the thornless erect cultivar, 'Navaho', producing a better root system than the thorny erect cuitivar, 'Cheyenne'. Treatment of 'Navaho' with 3000 and $8000 \mathrm{ppm}$ indolebutyric acid (IBA) in water and treatment of 'Cheyenne' with 8000 ppm IBA in water and 3000 ppm IBA in talc improved rooting.

AN INTEGRATED PEST MANAGEMENT EXTENSION PROGRAM FOR NURSERY PRODUCERS IN SOUTH CAROLINA

J.T. Moody* and M.C. Halbrooks, Department of Horticulture

Clemson Úniversity, Clemson, SC 29634-0375

The ornamental horticulture industry in South Carolina has expanded significantly over the last decade. Today, concerns regarding environmental and public health, and stricter regulations of pesticide use, are creating incentives for growers to evaluate alternative methods of pest control. Nursery producers currently use an array of chemicals in an attempt to control pests including insects, weeds, and diseases. Integrated pest management (IPM) provides an opportunity to reduce chemical reliance. The overall objective of this extension program is to collect and collate information relevant to the implementation of an IPM program. The first year, 1989-90, surveys were developed to determine key factors related nursery pest management. Types of data collected included: key pest species; pest-plant relationships; grower action responses to pest problems; types and frequency of pesticide use. The second year, 1990-91, involved implementing IPM strategies such as: cultural methods; use of horticultural oils, soaps, and lower risk pesticides; and spot treatment applications to help maintain pest populations below economically damaging levels. Improvements in pest management included; reduced chemical applications, reduced associated environmental risks, and maintenance of aesthetic quality of plants.

CHANGES IN ORGANIC ACIDS AND OTHER COMPOSITIONAL AND PHYSIOLOGICAL ATTRIBUTES OF PEACHES DUE TO CHILLING INJURY.

T. Wang*, A. R. Gonzalez, E. E. Gbur and J. M. Aselage, Department of Food Science, University of Arkansas, Fayetteville, AR 72703

Babygold 5 (BG5) and Redhaven (RDH) peaches at maturity 4 were held at $2.3^{\circ} \mathrm{C}$ for 0,2 and 4 weeks. After each cold storage treatment half of the fruit sample was evaluated; the other half was ripened for 8 days at $21^{\circ} \mathrm{C}$ and respiration was measured daily. The evaluations on both samples were for malic, citric and quinic acids, titratable acidity (TA), soluble solids (SS) and flesh firmness. Malic acid in ripened BG5 and RDH Fruits increased relative to their unripened counterpart over the cold storage time; citric acid increased in BG5, decreased in $\mathrm{RDH}$; quinic acid decreased in both cultivars; TA increased; SS decreased in BG5, did not change in RDH; flesh firmness increased in BG5, did not change in RDH. Respiratory rate increased with cold storge time in both cultivars. overall, BG5 showed more susceptibility to chilling than RDH.

COMPARISON OF ZYGOTIC AND SOMATIC EMBRYOGENESIS IN CERCIS CANADENSIS

L.G. Buckley* E.T. Graham, and R.N. Trigiano, Dept. of Ornamental Horticulture and Landscape Design, University of Tennessee, Knoxville, TN 37901-1071.

Zygotic and somatic embryos are purported to follow similar developmental sequences, but few investigations have thoroughly compared the two processes. Developing pods of Cercis canadensis $L$. (redbud) were collected from trees on the Knoxville campus of the University of Tennessee once or twice per week from 28 March to 8 August 1991. At least 10 ovules/sample date were fixed in FAA to evaluate zygotic embryo ontogeny. A minimum of 40 ovules/sample date were aseptically excised and placed on SH medium supplemented with 9.0 $\mu \mathrm{M} 2,4-\mathrm{D}$ and $5 \mathrm{mM}$ ammonium ion to initate somatic embryogenesis. Zygotic and somatic embryos were prepared for histological examination using standard paraffin techniques. Somatic embryos developed primarily from cotyledons and epicotyls of zygotic embryos that were cultured between 6 June and 19 July. Somatic and zygotic embryos were subtended by multiseriate suspensors and progressed through recognizable globular, cordate and cotyledonary stages of development. Cotyledon morphology was similar for both embryo types. However, many somatic embryos failed to differentiate dome-shaped shoot meristems exhibited by their zygotic counterparts.

COLD HARDINESS OF PASSIFLORA SPECIES

Patricia Quesada* and Frank B. Matta, Department of Horticulture, Mississippi State University, Mississippi State, MS 39762

Two species of Passiflora, $\underline{P}$. edulis $f$. edulis (purple passion fruit) and $P$. edulis $\bar{f}$. flavicarpa (yellow passion fruit), and $P$. incarnata (maypop), were evaluated for acclimation and cold hardiness, using differential thermal analysis, electrolyte leakage and the tetrazolfum stain test. The two species showed the capacity to acclimate several degrees during the evaluation period and the three tests gave simflar lethal temperatures for the two species; $-9 \mathrm{C}$ to $-10 \mathrm{C}$ for yellow passion fruit, $-10 \mathrm{C}$ to $12 \mathrm{C}$ for purple passion fruit and $-11 \mathrm{C}$ to $-13 \mathrm{C}$ for maypop. Purple and yellow passion fruit were also assayed for survival after a freeze-thaw cycle, using a tissue culture regeneration technique called "feeder plate". Yellow passion fruit did not show the capacity to regenerate at any of the temperatures used $(0,-3,-6 C)$. Purple passion fruit showed callus formation even at the lowest temperature $(-6 \mathrm{C})$.

EFFECT OF ROOTSTOCK AND ORCHARD FLOOR MANAGEMENT ON CARBOHYDRATE LEVELS OF 'REDHAVEN' PEACH

Danielle R. Ellis* and Gregory L. Reighard, Department of

Horticulture, Clemson University, Clemson, SC 29634-0375 Trees of 'Redhaven' peach [Prunus persica (L.) Batsch] budded to 'Lovell', 'Bailey', and 'Nemaguard' rootstocks were growil with bahiagrass or cultivated orchard middles. Terminal shoots were collected once a month through the dormant season. 'Redliaven' on 'Lovell' had significantly higher levels of sucrose, sorbitol, total soluble sugars, starch and total non-structural carbohydrates than 'Redhaven on 'Nemaguard'. However, there wcre no significant differences in any carbohydratc fraction between 'Redhaven' on 'Bailey' and the other rootstocks. Orchard floor management system had no significant effect on carbohydrate levels.

\section{Fruit Crops}

FERTILIZATION, TOPPING, AND HOLE SIZE FOR PECAN TREES AT TRANSPLANTING

Ray E. Worley, Department of Horticulture, University of Georgia, coastal Plain Experiment station, Tifton, GA 31793

Soil amendments of complete fertilizer, manure and limestone added to backfill soil at transplanting did not influence pecan tree appearance or growth. Removal of $1 / 3$ or $1 / 2$ of the top at transplanting was compared with no top removal. Removal of $1 / 2$ the top improved tree vigor the first year but differences in vigor and growth had dissipated by the second year. With $60 \mathrm{~cm}$ diameter holes, vigor and growth increased as depth increased from 30 to $90 \mathrm{~cm}$. Trees planted in a $20 \mathrm{~cm}$ diameter post hole had poorer vigor and growth the first two years than trees planted in $60 \mathrm{~cm}$ diameter $x 90 \mathrm{~cm}$ depth hole. Differences in vigor and growth due to hole size also dissipated with time and were not significant at the end of the third year. Pecan trees apparently are resilient and can overcome a poor transplanting job. 
INFLUENCE OF A SOIL SPIKE AERATOR ON INCREASING NUT SIZE AND YIELD ON PECAN TREES

Dan Chapman*. Laurence Sistrunk and J. Benton Storey, Department of Horticultural Science, Texas A\&M University, College Station, TX 77843-2133.

Objectives of this experiment were: 1) to measure the effect of a soil spike aerator on nut quality and yield, and 2) to see whether shallow chiseling influenced nut quality and yield. In 1990, a randomized design was set up in a 33 year old orchard on Westwood silty clay loam with 4 main treatment factors: 1990 nut size, chiseling, aeration, and cultivar. Location for this experiment was the Adriance Orchard on the Texas A\&M Plantation - Brazos River flood plain Nut quality was determined by the $\%$ kernel and \# nuts / kg. Yield was measured per tree and calculated for $\mathrm{g} / \mathrm{cm}^{2}$ cross-sectional trunk area. The soil bulk density for each treatment was $1.53 \mathrm{~g} / \mathrm{cm}^{3}$ and found to be statistically uniform at the start of the experiment. Rcsults after one year showed that aeration increased the nut size and \% kerne of 'Mahan' but not of 'Desirable' and 'Stuart'. Chiseling increased the yield of 'Stuart' and 'Desirable' and nut size of all 3 cultivars but not $\%$ kernel. Aeration increased the \% kernel from a mean $48.6 \%$ to $56.8 \%$ and nut size from 129 nuts $/ \mathrm{kg}$ to 102 nuts $/ \mathrm{kg}$ of the 1990 small-nut-size trees but did not significantly increase nut quality for the 1990 normalnut-size trees.

PECAN FRUIT GROWTH AND EMBRYO DEVELOPMENT Hazel Y. Wetzstein ${ }^{*}$ and Amnon Levi, Department of Horticulture, University of Georgia, Athens, GA 30602

Embryogenesis in higher plants follows a standard developmental program with sequential stages of histodifferentiation, maturation (reserve deposition), and postabscission (desiccation and rapid decline in metabolic activity). In this study, morphological, physiological and anatomical characteristics were integrated to demarcate the developmental stages of pecan embryos. Fruit were collected, morphological characteristics were recorded, fresh and dry weights, and water content of embryos were determined, and embryos were prepared for microscopic study. The procedures used here can be a useful guide for characterizing embryo development in pecan and related species.

EFFECT OF VARIOUS METHODS OF PACLOBUTRAZOI APPLICATION ON CHERRY TREE PERFORMANCE AND SOII RESIDUE. T.Jacyna* and K.G.Dodds, RR 2,Box 256, Loulsina, Missouri 63353 .

Four-year old sweet cherry trees of cv.Bing growing in HDP (1481 trees/ha) were treated with paclobutrazol(PBZ) as trunk drench(T), shank(S) and paint $(\mathrm{P})$ application at standart rate $15 \mathrm{mg} \mathrm{PBZ} / \mathrm{cm}^{2}$ of trunk cross sectional area. All chemical treatments caused a significant reduction in total extension growth and shoot length as compared with the control. No significant differences in yield, fruit firmness,\% soluble solids, fruit stalk length and fruit weight between the treatments were found. 18 months after PBZ application in the orchard, the PBZ soil residue was assessed by means. of bioassay. Indicator plant produced 23.6, 56.1 and 70.5 percent of control growth when grown in the soll taken from T, S and $\mathrm{P}$, respectively. $\mathrm{P}$ and $\mathrm{S}$ were able to significantly reduce $P B Z$ soll residue without decreasing the effectiveness of PBZ and any adverse effects on fruit yield and quality.

\section{SOIL INJECTION OF BAS 111-06W REDUCES SHOOT GROWTH IN PEACH}

Gregory L. Reighard, Clemson University, Sandhill Research and Education Center, P.O. Box 23205, Columbia, SC 29224-3205

The growth regulator BAS 111-06W was applied twice each spring for 3 years to 5 -year-old 'Loring' trees. First year treatments were foliar sprays ( 1 or $2 \mathrm{~g}$ a.i.), trunk paints ( 2 or $4 \mathrm{~g}$ a.i.), and soil shank injections ( 2 or $4 \mathrm{~g}$ a.i.). Foliar treated trees developed severe leaf shotholing or bacteriosis. Shank treatments were the most effective in controlling shoot growth. Thus, second and third year treatments consisted only of the shank applications. Both the 2 and $4 \mathrm{~g}$ rates were equally effective in reducing shoot elongation $10-34 \%$ annually. Treated trees bloomed 1-2 days earlier and had shorter bloom periods than the controls. Flower bud density and flower number were greater on treated trees. Fruit yields were not affected. Treated trees required less summer and corrective winter pruning, but had more short shoots to thin out.
EFFECTS OF DORMEX ON REPLACING LACK OF WINTER CHILLING IN PEACHES ALONG THE GULF COAST

*Arlie A. Powe11. Scott Goodrick, James Witt, William Dozier, Jr., and Richard Murphy, Horticulture Department, Auburn University, AL 36849

Lack of winter chilling can be a serious problem for commercial peach producers in the Southeast. Studies were conducted over 3 years (1989-91) to evaluate the effects of hydrogen cyanamide (Dormex-SKW) on replacing lack of winter chilling on 7 varieties of peaches. This study specifically reports on the effects of hydrogen cyanamide on 'Ruston Red' peach, a 850-hour variety.

Results from 1990 studies using whole tree sprays to the point of runoff indicated a problem with the efficacy and phytotoxicity. In 1991, a combination of hydrogen cyanamide $(49 \%)$ rates $(0,0.5,1,2$, and $4 \% \mathrm{v} / \mathrm{V})$ and timings $(0,25,50$ and $75 \%$ of chilling level) were evaluated using 7-year-old 'Ruston Red' peach trees. Only 590 hours of chilling at $7.3^{\circ} \mathrm{C}$ and lower were accumulated at this site. Rates of $0.575 \%$ (actually only $70 x$ ) chilling level induced full cropping while control trees produced practically no crop.

\section{EXPERIENCES WITH SUMMER PRUNING CLINGSTONE PEACHES}

Curt R, Rom*, R, Bourne K, Kupperman, and R.E. Moran. Dept. of Horticulture and Forestry, University of Arkansas, Fayetteville, AR 72701.

Summer pruning effects on processing peach on fruit quality, light penetration and interception, and \% defects was studied in 2 trials. In study A, pillar-trained trees were pruned with the following treatments: a control, summer pruning at stage II fruit growth, summer pruning post-harvest or, pruning twice (all trees dormant pruned). In the first year, pruning prior to harvest significantly increased blush and flesh firmness but reduced soluble solids content (SSC). In the second year, summer pruning reduced yield per tree and fruit drop (weight and \% of total) but did not affect fruit size, blush, or SSC. After 2 years, trees pruned post-harvest or twice had significantly smaller height, spread and trunk diameter. 1 In study B, 2 cultivars of central leader trained trees were pruned at stage II fruit growth in the following treatments: a control, canopy thinning, and hedging. Thinning pruning improved light penetration and hedging reduced light interception. Thinning pruning reduced $\%$ of fungal rotted fruit but did not affect fruit quality.

INTERACTION OF TRAINING SYSTEM, SUMMER PRUNING AND ROOT PRUNING ON YIELD AND CANOPY DENSITY OF PEACH ${ }_{\text {W.C. Olien }}{ }^{1 *}$, R.E. Williamson ${ }^{2}$, C.E. Hood ${ }^{2}$, D.R. Decoteau ${ }^{1}$ and D.C. Coston ${ }^{1}$, Departments of Horticulture ${ }^{1}$ and Agricultural \& Biological Engineering ${ }^{2}$, Clemson University, Clemson, SC 29634.

Factorial combinations of $-/+$ root pruning (RP) and $-/+$ summer pruning (SP) were initiated in 1991 as subplots within a Redhaven/Lovell study of orchard training systems: Open Center (OC), Y-Trellis (YT), Central Leader (CL), and Meadow Orchard (MO) established in 1985. Root pruning was imposed at bloom (March 28) at $76 \mathrm{~cm}$ from the trunk to a depth of $45 \mathrm{~cm}$. Summer pruning consisted of preharvest removal of water sprouts (June 5). Canopy density, quantified by transmittance of PAR radiation through the canopy, was greatest in OC and MO and least in YT and CL systems. SP and RP treatments further reduced canopy density by 35 to $80 \%$. There were no main or interactive effects of SP and RP on 1991 yields or fruit quality, and also no interactive effects of orchard systems with SP and RP. Thus, SP and RP reduced canopy density without negative effects on fruit. RP, however, advanced harvest date by ca 4 days. A parallel study was also initiated in 1991 to determine the effects of root pruning distance $(30,60,90 \mathrm{~cm}$ from the trunk, or no RP) on canopy density, yield, and fruit quality of mature, OC-trained Redhaven/ and Jefferson/Lovell. Reduction in canopy density without loss of yield or fruit size was obtained at a RP distance between 60 and $90 \mathrm{~cm}$.

PLANT HORMESIS INDUCED BY ULTRAVIOLET LGHT-C FOR INDUCING RESISTANCE OF BROWN ROT OF PEACHES

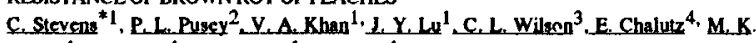
Kabwe $^{1}$, Z. Haung ${ }^{1}, 0$, Adeyeye ${ }^{1}$ and J. Liu ${ }^{1}$

${ }_{1}$ George Washington Carver Agricultural Experiment Slation, Tuskegee University, Tuskegee Institute, Alabama, 36088

${ }^{2}$ United States Department of Agriculture/Agriculture Research Service, Southeastern Fruit and Troe Nut Research Laboratory. Bymon,Georgia, 31008 ${ }^{3}$ United States Department of Agricuhure/Agriculture Research Service Appalachian Fruit Researeh Station, Kearneysvilke, Weat Virginia, 25430

$4_{\text {Agriculture Research Organization, Volcani Center, Bet Dagan, Israel }}$

Low hormetic doses of ultraviolet light (UV-C) stress on exposed peaches (Prunus persica), reduced brown rot resulting from field and artificial inoculation from Monilinis fructicola. To test the hypothesis that UV-C induced resistance through host responses the following tests involving biochemical changes (phenlyalanine ammonia-lyase 
activity (PAL) and ethylene production (EP)), biosssay of antifungal activity of tissue extracts to the fungus, and hatent infection of rot free peaches previously treated with and without UV-C were determined. Exposure of peaches to UV-C dose of $7.5 \times 10^{4} \mathrm{erg} / \mathrm{min}^{2}$ promoted an increase in PAL and EP compared to the control. As the PAL activity increased, percent storage rots decreased. Antifungal activity to the fungal conidia in UV $C$ treated peach extract showed that the percent conidia geminination was reduced 3 folds. Preharvest infection of brown met which indicated latent infection was significantly reduced. To test for the germicidal effect of UV-C on M. fucticols on the surface of peaches, an artificial epiphytic population of the fungus was deposited on the peaches. A negative relationship between UV.C dose of 1.3 to $40 \times 10^{4} \mathrm{ergs} / \mathrm{mm}^{2}$, colony forming units and number of decaying brown rot lesions were found.

SITE EFFECTS ON SUSCEPTIBILITY OF ASIAN PEARS TO FIRE BLIGHT T. Jones*, J. Strang, G. Brown and D. Wolfe, Department of Horticulture, University of Kentucky, Lexington, KY 40546 Kentucky is one of seven states in the southeast evaluating 13 Asian pear cultivars for sultabllity to the region. The cultivars were planted on a $\left(20^{\prime} \times 10^{\prime}\right)$ spacing in 1989 at three separate locations. Data on time of bloom, tree growth, fire blight susceptibility and fruit quality and yleld were collected. This study demonstrates the varlability seen in Asian pear cultivars in response to site. There was a significant site by cultivar interaction for fire blight. The Princeton site had significantly more fire blight than either Lexington or Quicksand. Four cultivars, Nitiaka, Shin L1, Shinko and Shinseikf had low fire blight ratings which were not significantly different between the three sites. Asian pear growth rates were significantly different between the three sites, but cultivar growth rates were not. Tree growth rate showed a signtficant negative correlation to fire blight rating. That is infected trees did not grow much. Initial findings show Shinko, Shinselki and Niltaka to have some tolerance to fire blight spread and to produce good ylelds of attractive fruit. However, Niltaka had a very tough skin with a tendency towards fruit cracking. The cultivar Shin Li which also had fire blight tolerance did not produce fruit or flowers.

COMPARISON OF INTEGRATED CROP MANAGEMENT AND A SCHEDULED PREVENTATIVE PEST CONTROL PROGRAM IN A COMMERCIAL APPLE ORCHARD Gerald Brown*, Ricardo Bessin, John Hartman, Dwight Wolfe, and John Strang, Research and Education Center, University of Kentucky, Princeton, KY 42445

Apple growers in Kentucky normally control pests on a preventative schedule involving fifteen or more chemical applications annually. IPM technology designed to provide growers information about the threat of diseases and insects was used in a demonstration plot in a Daviess County orchard and in the U.K. research orchard, Princeton. The IPM systems used in Daviess County resulted in 6 less applications of pesticides than the traditional system, a savings of approximately $\$ 130$ per acre. When compared to the traditional preventative spray schedule, the IPM treated apples showed no differences in fruit quality and in orchard diseases and insect infestations. The decreased pesticide use has the potential to reduce applicator exposure, residues on fruit, and the environmental impact of these chemicals. The result of this demonstration were shared with and received an enthusiastic response from growers, Extension personnel. students, consumers, and the news media. The profect demonstrated the feasibility of using apple IPM by a Kentucky grower, and it provided students an insight into applied biology.

\section{RELATIONSHIPS OF LEAF AREA AND TRUNK DIAMETER OF APPLE TREES AFFECTED BY ROOTSTOCK AND CULTIVAR}

Curt R. Rom and Renae E. Moran* Department of Horticulture and Forestry, University of Arkansas, Fayetteville, AR 72701.

Trunk cross-sectional area (TCA) has been used to estimate leaf area (LA) and yield efficiency but variation in LA and TCA relationships have been unexplored. LA and TCA of 10-yr-old 'Starkspur Supreme Delicious' on 9 rootstocks (STKs) were measured in 1989. LA and TCA of 2-yr-old trees of 3 cultivars (CVs) on 5 STKs were measured in 1991. Regression of LA and TCA was performed for each CV, STK and each CV/STK. On mature trees, LA varied significantly with STK. The number and LA of shoot leaves (LVS) and spur LVS varied with STK but the \% of total was not significantly different (approx. 52\% spur LYS). The relationships of LA and TCA were linear for mature $\left(r^{2}=.94\right)$ and young $\left(r^{2}=.44\right)$ trees. On young trees, TCA varied with CV, but LA did not. Both LA and TCA were significantly different among STKs. The linear relationships of LA and TCA had unique intercepts with each CV, STK, and CV/STK combination but slopes were not significantly different. Leaf area of 'Jonagold' and 'Gala' tended to increase more with increasing TCA than 'Empire'.
COLD PROTECTION OF KIWIFRUIT PLANTS WITH TRUNK WRAPS AND MICROSPRINKLER IRRIGATION

D.G. Himelrick*, W.A. Dozier, Jr, and A.W. Caylor, Auburn

University, Auburn, AL 36849

Own-rooted four-year-old kiwifruit plants (Actinidia deliciosa) protected by a Reese clip-on styrofoam insulation trunk wrap, or microsprinkler irrigation, sustained less freeze injury than unprotected plants under field conditions at temperatures as low as $-17.8 C$. Trunk splitting occurred on the plants but no injury was detected on canes, buds, or shoots in the canopy of the plants. Unprotected plants had more trunk splitting and at greater heights than protected plants. New canes developed from suckers of cold-injured plants and developed a filled canopy the following season.

USING GEL POLYMERS TO INFLUENCE FERTILIZER NITROGEN RECOVERY BY STRAWBERRY

Douglas D. Archbold, Department of Horticulture and Landscape Architecture, and Charles T. MacKown, USDA-ARS, Department of Agronomy, University of Kentucky, Lexington, KY 40546

Three gel polymers, Hydrosource, REAP, and Agri-gel, wetted with solutions of ${ }^{15} \mathrm{~N}$-ammonium nitrate, were evaluated for controlled release of fertilizer nitrogen (N) to strawberry (Fragaria $X$ ananassa Duch.) in the greenhouse and field. Container-grown plants of 'Earliglow' and 'Allstar' were harvested every 2 weeks for 8 weeks. Field-grown plants of the same cultivars were collected from matted rows after harvest, and fruit were collected during harvest. Plant and fruit tissues were analyzed for total \% $\mathrm{N}$ and atom $\%{ }^{15} \mathrm{~N}$, and total fertilizer $\mathrm{N}$ recovery was calculated. For the container-grown plants, total \% $\mathrm{N}$ differed by cultivar, 'Earliglow' > 'Allstar', and harvest date, declining during 8 weeks. Treatment effects on total \% $\mathrm{N}$ were observed only in the field study, with Agri-gel showing the highest value. In the greenhouse study, Hydrosource and Agri-gel gave the highest tisste enrichments from fertilizer $\mathrm{N}$. In the field study, REAP and Agri-gel gave the highest enrichments. In spite of the greater tissue enrichments, however, no gel polymer significantly increased total fertilizer $\mathrm{N}$ recovery in either study.

THE EFFECT OF POST PLANT SOIL SOLARIZATION ON BLACK ROT OF 'CARLOS' MUSCADINE GRAPE

C. Slevers ${ }^{* 1}$, V. A. Khan ${ }^{1}$ L.Y.L. ${ }^{1}$ M. A. Wilson ${ }^{2}$, Z. Haung ${ }^{1}$ and J.E. Brown ${ }^{3}$ ${ }^{1}$ George Washington Carver Agricultural Experiment Station Tuskegee University, Alabama, 36088

2Deparment of Agriculture, Southeast Missouri State University, Miseouri State University, Missouri 63701-4799

${ }^{3}$ Department of Horticulture. Alabama Agricultunl Experiment Station, Auburn University Alabema, 36849

In 1988 and 1989 a muscadine vineyard at Tuskegece, Alabama was treated by post plant soil solarization (PSS) (covering of moist wil around 'Carlos' muncadine plants (Vitia cotundifolia Michx.) with clear polyethylene plastic mulch to achieve high soil temperature for 30 and 75 days,respectively during PSS. Grape plants grown in solarized soils showed increases in growh responac such as increased yield. Foliage of grape plants was evalualed for reaction to black rot inciled by Guignandia bidwellii. A significant reduction of the foliage discase black rot wh Guignandia bidweliii. A significant reduction of the foliage disease black sot observed. The number of lesions per leaf, lesion size and percent leaves with lesions were

THE USE OF FINE MESHED NETTING TO EXCLUDE PESTS OF THORNLESS BLACKBERRIES AND GRAPES

J. Strang*, J. Harman, R. Bessin, T. Jones, G. Brown, T. Bames, T. Yankey, and J. Snyder, Department of Horticulture, University of Kentucky, Lexington, $\mathrm{KY} 40546$

Four different netting types were evaluated in the field for excluding Japanese beetles and green June beetles from 'Dirksen' thomless blackberry plants. These nets were bird net, crop net, rack mesh, and Agryl P17. Observations were made in an unreplicated trial on 'Reliance' grapes using OV3018 and OV7100 nets in addition to those listed. Plants were not sprayed with insecticides or fungicides after net application. Rack mesh appears to be the best net of those evaluated during a dry season for excluding Japanese beetles and green June bectles on thomless blackberries and grapes. Plants covered with rack mesh had minimal fruit and foliage damage duc to insects and fruit rot. The use of rack mesh climinated the need for insecticide sprays for 53 days on thomless blackberries and 41 days on grapes. Light intensity was reduced by the netting, but did not reduce thomless blackberry yield or soluble solids; lowever it did unacceptably reduce 'Reliance' grape fruit coloration. 
NEW BLACKBERRY AND GRAPE CULTIVARS FOR THE SOUTH J.N. Moore*, John R. Clark and Jugtin R. Morris, University

The impending release of a new blackberry cultivar and new grape cultivar by the University of Arkansas Agricultural Experiment Station will be discussed. The blackberry, tested as A-1536, is an erect, thornless type rlpening two weeks before 'Navaho'. It produces very $\mathrm{f}$ i rm highly flavored fruit similar to 'Navaho'. The grape, tested as A-1335, is a blue-seeded juice grape with good adaptation to areas with high summer temperatures where 'Concord' does not ripen evenly. Fresh frult and processed fuice quality has been rated equal to or better than concord' juice for quality attributes.

HARVEST AGE EFFECT ON YIELD OF ERECT BLACKBERRIES John $R$. Clark* and James $N$. Moore, University of Arkangas

Yield and average berry weight were measured for first year fruiting (on semi-erect canes) and second year fruiting (erect canes) to compare harvest age effect for erect blackberries established from root cuttings. Cultivars were 'Cheyenne'. 'Choctaw', 'Navaho' and 'Shawnee' and 4 plantings were included in the comparison. one of the four plantings had an average yield of 278 more in the first year as compared to the second year. The other plantinga had higher ylelds in the second year as compared to the first ranging up to a $100 \mathrm{~s}$ increase. Yield was 23 higher for the second year when all plantings wer averaged. Average yield increase by cultivar in the second year compared to the first was: 'Choctaw' 378, 'Cheyenne' 278, 'Navaho' 228 and 'Shawnee' 208. Berry weight was not affected by harvest age except in one planting where affected by harvest age except in one planting

\section{RABBITEYE BLUEBERRY RESPONSES TO HERBICIDES}

D.G. Himelrick* and W.A. Dozier, Jr., Auburn University, Auburn, AL 36849-5408

Rooted rabbiteye blueberry cuttings were transplanted to $15 \mathrm{~cm}$ pots containing either builders sand or $80 \%$ sand 20 peatmoss $\mathrm{v} / \mathrm{V}$ (1\% OM). Five different herbicides were applied at the high and low recommended rates. Terbacil at 1.4 or $2.9 \mathrm{~kg} / \mathrm{ha}$ a.j. caused a $72 \%$ mortality while 1.8 or $3.6 \mathrm{~kg} / \mathrm{ha}$ a.i. application of norflurazon caused a $53 \%$ mortality. Root volume, weight, top weight, and leaf chlorophyll concentrations were reduced by terbacil treatment. Oryzalin at $2.7 \mathrm{~kg} / \mathrm{ha} \mathrm{a.i}$. or norflurazon at $3.6 \mathrm{~kg} / \mathrm{ha} \mathrm{a.j}$. reduced root and top weight and chlorophyll. Napropamide at $2.2 \mathrm{~kg} / \mathrm{ha}$ a.i. reduced top weight and chlorophyll. Two good choices for young plants appear to be simazine at $1.8 \mathrm{~kg} / \mathrm{ha}$ a.j. and napropamide.

VEGETATIVE DEVELOPMENT EFFECTS ON NITROGEN AND CARBOHYDRATE PARTITIONING IN BLUEBERRY

Donald J. Merhaut and Rebecca L. Darnell, Department of Fruit Crops, IFAS, University of $\mathrm{FL}$ Gainesville, FL 32611.

The influence of stage of vegetative flush development on $\mathrm{NH}_{4} \mathrm{NO}_{3}-\mathrm{N}$ uptake and carbon and nitrogen partitioning was evaluated in two-year-old 'Climax' rabbiteye blueberries using dual labeling with ${ }^{15} \mathrm{~N}$ and ${ }^{14} \mathrm{C}$. Plants were grown in sand and fertilized with a modified Hoagland's solution. Plants were pruned to induce three stages of vegetative development: flush initiation, midflush, and flush maturity.

Total nitrogen uptake did not differ for the different stages of growth. However, $\mathrm{N}$ allocation to leaves was greatest at mid-flush, possibly due to higher transpiration rates of developing leaves. Total ${ }^{14} \mathrm{C}$ partitioning to roots was reduced at midflush, compared to the other growth stages, reflecting the increased demand for carbon by growing shoots. Although less carbon was allocated to roots at mid-flush, this did not 1 imit $\mathrm{N}$ uptake.

NITROGEN RATE AND TIME OF SAMPLING EFFECTS ON SOIL TEST VALUES C $?$ HIGHBUSH BLUEBERRIES GROWN ON A MINERAL SOIL John $R$. Clark*, Kelly M. Irvin and Richard Mapleg, 72830

Nitrogen rates (using urea) of 22,67 and $135 \mathrm{~kg} / \mathrm{ha}$ were applied to mature mulched and unmulched highbush blueberries over a 5 year period. Soll samples were taken each year at budbreak (prior to fertilization) and postharvest at the suggested time of follar sampling (approx. Aug. 1) to determine $N$ rate effects within and among years. Data analysis revealed that the most common soil test varlables affected by $\mathrm{N}$ rate and date of sampling were $\mathrm{pH}$, variables affected by $\mathrm{N}$ rate and date of sampling were $\mathrm{pH}$, electrical conductivity $(\mathrm{EC})$ and nitrate. For unmulched plants, a significant reduction in soil pH was found each
year between budbreak and Aug. 1 for the 67 and $135 \mathrm{~kg} / \mathrm{ha}$ rates, but not usually for the $22 \mathrm{~kg} / \mathrm{ha}$ rate. For mulched plants, $\mathrm{pH}$ reduction within $\mathrm{N}$ rate among sample dates was usually not significant. Overall soll pH reduction was greatest for the $135 \mathrm{~kg} / \mathrm{ha}$ rate over the 5 years, and the $\mathrm{pH}$ reduction for the $67 \mathrm{~kg} / \mathrm{ha}$ rate was 8 imflar to the 135 $\mathrm{pH}$ reduction for the $67 \mathrm{~kg} / \mathrm{ha}$ rate was $81 \mathrm{millar}$ to the 135 $\mathrm{kg} /$ ha rate $\mathrm{cor}$ unmulched plants. For mulched plants, 22 and $67 \mathrm{~kg} / \mathrm{ha}$ rates had a similax trend of only a slight pH reduction over the 5 years. EC and nitrate trends were very similar, with the highest levels of each on the
unmulched plants.

\section{Vegetable Crops}

\section{EFFECTS OF BIWEEKLY TOPPING ON NUTRIENT CONTENT OF} SHOOT TIPS AND STORAGE ROOT YIELD OF SWEETPOTATO GROWN IN A NFT SYSTEM

P.P. David* A. Almazan, C.K. Bonsi, D.G. Mortley and A.A. Trotman, G.W. Carver Agricultural Experiment Station, Tuskegee University, Tuskegee, AL 36088.

Studies were conducted in a greenhouse to determine the effects of harvesting sweetpotato (Ipomea batatas L. (Lam.) cv. "TI-82-155") shoot tips (top $10 \mathrm{~cm}$ ) at biweekly intervals beginning 42 days after transplanting on yield of storage root and nutrient content of harvested shoot tips. Plants were grown hydroponically from vine cuttings of $15 \mathrm{~cm}$ length, planted in $0.15 \mathrm{x}$ $0.15 \times 0.12 \mathrm{~m}$ growth channels using a closed NFT system. Nutrient was supplied in a modified half-strength Hoagland's solution with a N:K ratio of 1:2.4. Final harvest was at 120 days when shoot biomass and yield of storage roots were measured. Biweekly topping did not affect storage root yield or shoot biomass. However, harvesting time had a significant effect on dry matter and nutrient content of shoot tips.

\section{EFFECT OF INOCULATION WITH AZOSPIRILLUM BRASILENSE ON FOLIAGE AND STORAGE ROOT YIELD OF SWEETPOTATO GROWN HYDROPONICALLY IN AN NFT SYSTEM} A.A. Trotman, D. G. Mortley and P.P. David, G.W. Carver Agricultural Experiment Station, Tuskegee University, Tuskegee, AL 36088 .

The effect of inoculation of sweetpotato (/pomea batatas $L$. (Lam.)) cultivar "TI-82-155" with Azospirillum brasilense was investigated in an observational greenhouse experiment. Sweetpotato was grown in a closed hydroponic system and plant nutrients were supplied in a Modified Half-strength Hoagland's solution (N:K 1:2.4) using a nutrient film technique system (NFT). Plants were either supplied with mineral nitrogen (160 ppm) and noninoculated or were supplied mineral nitrogen $(160 \mathrm{ppm})$ and inoculated. Storage root dry matter was higher under inoculation with $A$. brasilense. Inoculation also increased the percent total nitrogen in the shoot, leaves, and fibrous root. There was a significant difference in fresh fibrous root weight for the inoculated $(262.5 \mathrm{~g})$ over the noninoculated $(177.1 \mathrm{~g})$ treatments. Mineral nitrogen supplied in the PNS was not limiting because dry matter for plants inoculated with $A$. brasilense was not significantly higher than for the noninoculated control.

SWEET POTATO AS A CROP FOR SOIL CONSERVATION Iris Cole-Crosby *,Patrick Igbokwe, Jesse Harness, Alcorn State University, Lorman, MS 39096 and Lois Ascough, National Soil Erosion Lab, West Lafayette, IN.

Most of the research on soil erosion has been done on traditional crops such as cotton, field corn and soybean and not vegetables. The USDA-ARS United States Department of Agriculture-Agricultural Research Service had developed a process based erosion prediction program called Water Erosion Prediction Project (WEPP). Alcorn is providing data for the validation of this model for selected fruits and vegetables. WEPP was run for sweet potatoe and cotton using a 10 year simulation. Some input parameters were row width tillage sequences and depths, rainfall, temperature canopy width, canopy cover, vegetative dry matter and leaf area index. The results from WEPP is given as soil loss for $50 \mathrm{M}$ at increments of . $5 \mathrm{M}$. There was a significant difference in the amount of soil lost from sweet potato when grown as a single crop as compared with cotton. 
EFFECTS OF TEMPERATURE REGIMES ON TOMATO SEEDLING DEVELOPMENT Senshan Yang* Joanne Logan and David L. Coffey

Univ. of Tenn. Dept. of Plant and Soll Science, Box 1071, Knoxville, TN 37901-1071.

To investigate effects of temperatures in the preceding developmental stage on the following developmental stage, 'Sunny' tomatoes were seeded in the greenhouse at six dates and three temperature levels. Plants were rotated among temperature levels so that all plants received approximately the same temperature accumulation at the time of field transplanting. Developmental stages defined were: emergence, $1 s t, 2 n d, 3 \mathrm{rd}, 4 \mathrm{th}, 5 \mathrm{th}$, and $6 \mathrm{th}$ leaf appearance. Temperature and solar radiation were recorded hourly. Results indicated a significant effect of temperature in the preceding stage on the following stage Coefficients of variation (CV) in growing degree days (GDD) calculated from the 1st to the ith stage were significantly smaller than those calculated from the (i-1)th to ith stage. When $R_{i}$, defined as the reciprocal of the number of days from the 1 st to the 1 th stage, was regressed to $R_{i-1}$ and the daily average temperature was regressed from the $(i-1)$ th to the ith stage, all coefficients of $R_{1-1}$ were significant at the 18 level. This model was superior to one in which $R_{1}$ was regressed to the dafly average temperature from the 1 st to the ith stage.

EFFECTS OF SOIL FUMIGANTS (METHAM SODIUM VS. METHYL BROMIDE) AND PLASTIC MULCH ON YIEID OF TOMATOES

Steve Kovach ${ }^{*}$ and James Brown, Department of Horticulture, Walter Hogue, E.v. Smith Research Center, Larry Curtis, Agricultural Engineering Department, and William S. Gazaway, Plant Pathology Department, Auburn University, Al labama 36849. 5630

Drip-irrigated tomato ('Sunny') plants were treated with five levels of fumigant in combination with three levels of mulch. Fumigants were metham sodium at two rates, 475 and $950 \mathrm{~L} / \mathrm{ha}$, a $67 \%$ methyl bromide $+33 \%$ chloropicrin formulation $(164.5 \mathrm{~kg} / \mathrm{ha}$, and a $98 \%$ methyl bromide $+2 \%$ chloropicrin formulation $(329 \mathrm{~kg} / \mathrm{ha})$. Mulching levels were $1.25 \mathrm{mil}$ silver on black polyethylene (plastic), blue-black latex mulch sprayed over the plant beds, and no mulch. Plants treated with metham sodium $(950 \mathrm{~L} / \mathrm{ha}$ ) had a significantly higher number of marketable fruit than plants treated with no fumigant or the $98 \%$ methyl bromide $+2 \%$ chloropicrin formulation. Marketable fruit weight was not significantly affected by the five fumiqation levels. Plants grown with black plastic mulch had a significantly higher marketable yield than plants grown with no mulch, $58,100 \mathrm{~kg} / \mathrm{ha}$ vs. $50,800 \mathrm{~kg} / \mathrm{ha}$, respectively. The level of mulching did not significantly affect the marketable number of fruit.

\section{INTRODUCTION OF A PLASTICULTURE SYSTEM}

D. C. Sanders*, Dept. of Horticultural Science, North Carolina State University, Raleigh, NC 27695 We instituted a series of on-farm trials to introduce vegetable growers to plasticulture systems. Initial trials were large areas where all combinations of plastic mulch, soil fumigation with methyl bromide, and drip irrigation were compared. As the system developed $0.4 \mathrm{Ha}$ trials were instituted to show system potentials. Later $0.1 \mathrm{Ha}$ trials were used to reduce resource demand. Low volume wells were used as a water source for drip irrigation. Often a simple venturi was used to apply fertilizer. Sand filters were made portable by placing them on a trailer and other equipment was made more portable. As more growers adopted the system demonstration became more complex and the focus changed to developing a total, intensive cropping system. In 10 year 50 demonstrations were conducted with a high of 18 , and the hectarage of plasticulture increased from $100 \mathrm{Ha}$ to $3500 \mathrm{Ha}$ or from $0.1 \%$ to $8 \%$ of the appropriate crops. Yields were increase 2 to 6 times with similar improvements in quality.

\section{YIELD LOSSES FR̄OM DELAYED HARVEST OF PAPRIKA PEPPER}

Brian A. Kahn", Department of Horticulture and Landscape Architecture, Oklahoma State University, Stillwater, OK 74078-0511

Paprika pepper (Capsicum annuum L.) plants were subjected to a single destructive harvest in either October, Novernber, or December to determine an optimal month for once-over harvest. Studies were conducted at two locations in Oklahoma each year for two years. Total and marketable fruit yields were highest with October harvest dates in three of the four experiments. Marketable fruit red color intensity decreased between the November and December harvest dates at both locations in the second year. It appears that paprika harvest should be completed during October in this region.
INFLUENCE OF ROW TUNNELS ON POTATO PRODUCTION IN MISSOURI Mack A. Wilson* and Victor A. Kahn, Department of Agriculture, Southeast Missouri State University, Cape Girardeau, MO 63701 and George Washington Carver Agricultural Experiment Station, Tuskegee University, Tuskegee, AL 36083 .

Four row covers (clear and white slitted), spunbonded polyester, and VisPore were used on 'Atlantic' potato cultivar at Charleston, Missouri. Row covers were installed on March 6, 1991 and removed on May 5, 1991. No significant differences were observed with orthoganal comparisons on grade A, B, and total number of potatoes among row covers. Total yields were higher with row covers and the data was significant. Potato plant heights were greater with row covers and the data was significantly different when the control was compared with row covers.

\section{ECONOMIC ANALYSIS OF POST HARVEST HANDLING METHODS FOR} FRESH MARKET MIXED GREENS

Paul W. Teague* and Tina G. Teague, Agricultural Research, P.O. Box 2043, Arkansas State University, State University, AR 72467

Several common methods of post harvest handling and pre-cooling for fresh market bunched greens (turnips, smooth and curly mustard, and collards) were evalusted. Six treatments were evaluated where greens were rehydrated and precooled using different combinations of hydrocooling, slush ice, and shoveled ice with three rehydration methods (hydrocooling, water drench, and water floating). Product temperatures were monitored and overall quality ratings were made after seven days in cold storage. Product quality after seven days was best with hydrocooling and insignificant differences in quality were recorded whether in-box ice was shoveled or slush ice. Turnips were most sensitive to degradation if precooled inadequately. Collards were the least sensitive. Economic analysis was completed using labor and ice cost differentials of selected packing and cooling methods to calculate product volume levels required to amortize relatively high costs of the hydrocooler, slush icer, and ice machine. Extremely large volume is required to fully amortize equipment acquisition costs based on labor cost savings alone. Greater cost savings per box, when comparing the cost of purchased ice to homemade ice, resulted in much lower volume requirements for full amortization. The results indicate that a producer with limited capital would benefit the most economically from acquiring an ice machine. The greatest quality benefit is gained from precooling with the hydrocooler.

REFLECTIVE PLASTIC MULCHES REDUCE APHID POPULATIONS AND THE SPREAD OF MOSAIC VIRUSES IN SUMMER SQUASH J.E. Brown*, R.P. Yates and W.T. Hogue, Department of Horticulture, AAES, Auburn University, AL 36849, and C. Stevens and V.A. Khan, Tuskegee Institute, AL 36088

Yellow crookneck 'Dixie' hybrid summer squash, Cucurbita pepo L. var. melopeop Alef., was evaluated at E.V. Smith Research Center, Shorter, Alabama. Summer squash was grown in single rows spaced 6 feet apart. Plants were seeded 18 inches apart within 20-foot row plots. Treatments were: 1) black plastic mulch (BPM), 2) yellow painted plastic mulch (YPM), 3) white plastic mulch (WPM), 4) bare soil (BS), 5) aluminum painted plastic mulch (APM) and 6) bare soil with Diazinon insecticide (BSI). Aphid traps caught more aphids in BS or BPM plots than those from APM or YPM plots. The onset of mosaic disease incidence of squash infected with the two viruses ident ified as zucchini yellow mosaic and cucumber mosaic was delayed by as much as three weeks when compared to BSI or BS. Summer squash planted in APM, WPM, YPM and BPM produced $96 \%, 98 \%, 75 \%$ and $21 \%$, respective $1 y$, more total squash yield than that produced on bare soil (control). A higher percentage of green squash (virus infected) was produced from plants grown over BPM (72\%), BSI (68\%), BS (59\%), YPM (57\%) or WPM (57\%) than from APM (39\%)

SCHEDULING MELON TRANSPLANTING TO MEET SPECIFIC HARVEST WINDOWS IN SOUTHWEST INDIANA

James E. Simon, W. Dennis Scott*, and Gerald Wilcox, Department of Horticu1ture, Purdue University, West Lafayette, IN 47907.

A study was initiated at the Southwest Purdue Ag Center to demonstrate the effect of transplant age and transplenting date on the scheduling of melon harvests. Muskmelon (Cucumis melo cv. Superstar) was seeded into $\$ 38$ growing trays with Jiffy-mix media. Seeding dates were such that 14 and 21 day old seedlings were transplanted Apri1 25, May 9, 17 and 24. The plants were grown on black plastic with trickle Irrigation Marketable fruit were harvested starting on June 28 and continuing through August 12. Neither transplant age or date had a significant effect on the number of fruit harvested or on total yield. However, each transplant date showed a distinctive harvest peak beginning June 30 for the Apri1 26 transplant then June 7,14 and 21 for each successive transplant date. 
CROPPING COLLARDS AND WATERMEL ONS USNG THE SAME PLASTIC MULCHES AND ROW COVERS

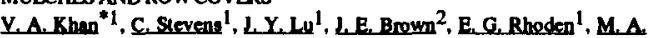

Wilson $^{3}$, M. K. Kabwe ${ }^{1}$ and Z. Heung 1

${ }^{1}$ George Washington Carver Agricultural Experiment Station Tuskegee University, Alabama, 36088

2Department of Horticulture, Alabama Agricuhural Experiment Station, Auburm University Alabama, 36849

${ }^{3}$ Department of Agriculture, Southeast Missouri State University, Missouri State University, Missouri $63701-4799$

An earty planting (January) of 8 wts. old collardo (Brassica oleracen (L) var. acephala 'Georgin Collards') and subsequently followed by 'Crimson Sweet' watermelon transplants (April) on elear and black polyethylene mulches and bare soil plus VisPore mw cover (VCM, VBM, VBS), clear and black polyethylene mulches and bare soil (CM, BM, BS) in combination with drip irrigation were transplaneed on the same plots. Marketable yield of collards (March) was significantly greater for mukched and row cover treatments than bare soil. Watermelon (harvested June 7 th, 1990) total and marketable numbers and yield were significantly greater when grown on mulched treatments than bare soil. Monocropping of watermelon were profitable under VCM, VBM, CM and BM treatments and collards when grown a a mo-crop was not profitable under any sytem. By haring collards when grown as a mono-crop was not profitable under any system. By sharing increased when grow

SEQUENTIAL CROPPING IN VEGETABLE AND TOBACCO PRODUCTION SYSTEMS UNDER VARIOUS TILLAGES WiILiam Terry Kelley"and David $\mathrm{L}$. Coffey, Univ. of Tenn. Dept. of Plant and Soll Science, Box 1071, Knoxville, TN 37901-1071.

Three cropping sequences and three tillage systems were evaluated under reduced tillage. Sequences were spring 'Packman' broccoli followed by 'Sunny' tomatoes or 'm.s. Ky 14 $\mathrm{X}$ L8 tobacco, spring broccoli/tomatoes or tobacco/fall broccoli, and tomatoes or tobacco/fall broccoli. Each sequence was grown conventionally tilled/no winter cover, conventionally tilled/wheat winter cover and no-till transplanted directly into killed wheat. The study was conducted at knoxville, (elev. 251m), Greeneville, (elev, 400m) and Crossville, (elev. 549 ) during 1989 and 1990 . Experiments were arranged in a strip-plot design with sequences stripped across tillages. No. 1 tomato yield was reduced in no-till at Greeneville (1989). Percentage of No. 1 tomatoes was not affected by tillage but the tomato-broccoli system produced a greater percentage at Greeneville (1990). Broccoli head size and subsequent yield was generally greater in conventionally tilled plots. Sequence generally had little affect on broccoli production. Yield and revenue of tobacco were generally lower in no-till treatments. Broccoli/tobacco sequences generally had the highest yield but varied by location. No-till produced lower quality tobacco both years at Knoxville but not at Greeneville.

PATTERNSOF STORAGE AND FIBROUS ROOT DEVELOPMENT IN SEVERAL SWEETPOTATO CULTIVARS AND THEIR PROGENIES

N. Bidiaks ${ }^{* 1}$, Y.A. Khan ${ }^{1}$, C. K. Bonsi ${ }^{1}$, C. Stevens ${ }^{1}$, E. G. Rhoden ${ }^{1}$, R.

Mortley ${ }^{1}$, and $R$. Ankhumah 1

IGeorge Washington Carver Agricultural Experiment Station Tuskegee University. Alabama, 36088

In 1991 keafless stem cutings 7 nodes long from 4 matemal parents ('Carver', Carver ii', TU-1892' and 'Georgin-Je') and their progenies (MP/P) were planted nodes deep in grcenhouse benches filled with Jiffy-Mix to determine if any similarity in storage (SR) or fibrous root (FR) patierns could be used to identify high yielding cukivars in a breeding program. The experiment was planted in a complete randomized block design with 7 seplications for each treatment and the total number of SR and FR data were collocted over a 9 wh period with weekly sampling. The results indicated that SR initiation was a continuos process and took from 5-9 wh before reaching a maximum level for some MP/P. There was a significant inverse relationship between SR and FR numbers, as SR increased FR docreased. SR for most MP/P were initiated at the underemound node closest to the soil surface and FR at the lower two nodes. When regression equations ware used on the gureenhouse data to lower two nodes. When regression equations were used on the greenhouse data 10 predict total number of SR that would be produced in a field trial, no significant differences were found between the number of SR initiated in the greenhouse and field trial 80 days affer transplanting by some of these MP/P. However, cuthivars with the highest number of atorage roots in the field trial did not have the highest number of marketable roots or yield and this was probably due to differences among MPP in the rate of not enlargement.

\section{IMPROVEMENT AND CULTURE OF CALABAZA [CUCURBITA MOSCHATA (DUCHESNE), POIR.]}

D. N. Maynard*, G. W. Elmstrom, L. Wessel-Beaver, and T, G. McCollum, Gulf Coast Research and Education Center, University of Florida, Bradenton, FL 34203

Calabaza is a pumpkin-like fruit that is grown throughout the tropics and subtropics. In the Caribbean "calabaza" is used in soups and other traditional dishes. In Puerto Rico, the 1987-88 calabaza crop was worth $\$ 8$ million and the value of the crop in Florida is estimated to exceed $\$ 5$ million. Mainland production of tropical calabaza types of $C$. moschata is limited largely to Florida where it is used mostly by those of Cuban descent. Despite the popularity and commercial significance of calabaza, little effort has been directed toward the study of cultural practices or varietal improvement. Only two improved varieties, 'Borinquen' introduced by the Puerto Rico Agricultural Experiment Station in the 1940s and 'La Primera' introduced by the Florida Agricultural Experiment Station in 1979 are available. Approaches to calabaza improvement including development of plants with shorter vines, incorporation of powdery mildew resistance, and production of uniform, symmetrical, hard-shelled, medium-sized fruit with enhanced nutritional quality in relationship to management systems are discussed.

EVALUATION OF WESTERN SHIPPER MELONS GROWN IN FLORIDA Gary W. Elmstrom*, Central Florida Research \& Education Center, Leesburg, FL 34748 and Donald N. Maynard, Gulf Coast Research \& Education Center, Bradenton, FL 34203 Muskmelon (Cucumis melo L. reticulatus group), commonly called cantaloupe by growers, shippers, and consumers is a relatively minor crop in the southeastern U.S. The principal restraint on increased muskmelon production in this area is the lack of varieties that consistently produce high quality fruit. Resistance to both fruit rots, especially those induced by Fusarium, and follar diseases such as downy mildew, powdery mildew, and gummy stem blight are also important because of the high humidity and frequent rainfall common to this area. The ideal shipping variety should have the capacity to produce high ylelds of round to oval, sutureless, heavily netted fruit that average $1.4 \mathrm{~kg}$ each, and that have a deep salmoncolored flesh, a small tight seed cavity, high soluble solids, and a pleasant taste and aroma. Evaluations at Leesburg and Bradenton, Florida over a three-year period have Identified several western-type muskmelons well-adapted to this area. 'Explorer', 'Goldmark', 'Mission', and 'Tasty Sweet' ranked high in most of the categories mentioned above and should be evaluated in more extensive trials, which should include a study of postharvest quality.

FRUTTING CHARACTERISTICS OF OKRA

Lurline Marsh*, Cooperative Research, Lincoln University, Jefferson City, MO 65102-0029

Thirty-seven okra (Abelmoschus esculentus) plant introductions and 3 cultivars, 'Clemson Spineless', 'Clemson Spineless $80^{\prime}$, and 'Candelabra Branching' were evaluated for their fruiting characteristics during a three year field study. Harvesting at 3 to $\mathbf{4}$ day intervals produced immature fruits which were approximately 4 to 7 days old. These inmature fruits when graded according to fruit length, were primarily very small $(<4.4 \mathrm{~cm})$ or small $(4.4-8.9 \mathrm{~cm})$. There were few medium $(>8.9 \mathrm{~cm}$ but $<12.7)$ or large $(>12.7 \mathrm{~cm})$ fruits. Of the 40 genotypes, Clemson Spineless averaged 46 pods per plant over 17 harvests. Few other plant introductions were comparable in the number of pods produced. Except for one, all other genotypes produced predominantly green fruits. Many of the genotypes were early maturing.

\section{NEW AU WATERMELONS}

J.D. Norton* G.E. Boyhan and B.R. Abrahams, Department of Horticulture, Al abama Agricultural Experiment Station, Auburn University, Alabama 36849

Disease is a major factor limiting production of watermelons in Alabama. Gummy stem blight, anthracnose, and Fusarium wilt are three of the most serious diseases, causing reduced yields of melons in certain fields in Alabama. Although satisfactory control of gummy stem blight and anthracnose may be accomplished with the proper application of organic fungicides during normal weather conditions, no control measure is effective during periods of high humidity and high rainfall. The discovery that certain plant introductions were resistant to gummy stem blight and race 2 anthracnose led to development of multiple disease resistant breeding lines that produce high yields of excellent quality fruit. This research resulted in the 1991 release of AU-Golden Producer and AU-Sweet Scarlet varieties that are resistant to gummy stem blight, Fusarium wilt, and anthracnose (Colletotrichum laginarium race 2 ). Both melons are superior to current varieties of their type in yield, quality, and disease resistance. 
EVALUATION OF WATERMELON AND RELATED GERMPLASM FOR RESISTANCE TO ZUCCHINI YELLOW MOSAIC VIRUS

George Boyhan ${ }^{\star}$. Joseph D. Norton, Barry J. Jacobsen, and Bruce $R$. Abrahams, Department of Horticulture and Plant Pathology, Auburn University, AL 36849.

of 153 plant introductions (PI), breeding lines, and commercial cultivars tested by mechanical inoculations in the greenhouse, only PI 482261-1, 'Egun', PI 494528, PI 386026, and PI 386025 showed any resistance to the Florida strain of zucchini yellow mosaic virus. PI 482261-1 and 'Egun' are Citrullus lanatus, the others are citron types, citrullus colocynthis. This is the first report of resistance in PI 386026, PI 386025, and the cultivar 'Egun'.

PA-136 CAYENNE PEPPER: A UNIQUE HOST FOR PRODUCING ROOT-KNOT NEAMTODE EGGS

P. D. Dukes* and R. L. Fery, U. S. Vegetable Laboratory, ARS, USDA, 2875 Savannah Highway, Charleston, SC 29414-5334

A useful and novel cayenne pepper (Capsicum annuum L.) breeding line has been released by ARS, USDA, U. S. Vegetable Laboratory. This new Line, designated and tested as PA-136, has a high level of tolerance to massive infection by root-knot neamtodes (Meloidogyne spp.) to which it is susceptible. PA-136 has proven to be useful as a host for the abundant production of eggs for several Meloldogyne species, Including all 4 races of $\mathrm{M}$. Incognita. Avallability of large quantities of egg inoculum of these obligate parasites is a pre-requisite for successful and efficient breeding for root-knot resistance. PA-136 plants are vigorous, strong and unfformly branched, and reach a helght of about $60 \mathrm{~cm}$. The line has many good horticultural traits, including high yield, deep red frult color, and high pungency. PA-136 is stable for all traits needed for the production of large numbers of viable eggs. Eggs are easily collected when needed from fresh roots using the Hussey-Barker extraction procedure (Plant Dis. Reptr. 57:1025-1028. 1973).

INTERACTION OF NITRAPYRIN, $N$ FORM AND N CONCENTRATION ON TOMATO GROWTH, N CONTENT AND RESIDUAL N CONTENT OF SOIL:SAND MEDIUM

David N. Sasseville* and Rufus Jones, Lincoln University, Jefferson City, Missouri 65101

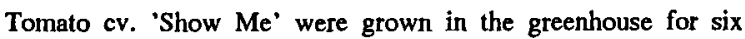
weeks in a $50 \% ; 50 \%$ (v:v) soil:sand mixture and provided weekly with a quarter-strength Hoagland solution with nitrogen provided as 100\%:0\% $50 \% ; 50 \%$ 0\%:100\% nitrate:ammonium ratios at rates of $0,10,20,40,80$ $\mathrm{mg} \mathrm{N} / \mathrm{kg}$ medium with and without $5 \mathrm{mg} / \mathrm{kg}$ nitrapyrin. Nitrapyrin induced plant phytotoxic symptoms of stunted growth, curled leaves and deformed terminal buds. These effects were reduced with increasing amount of applied nitrogen and greater percent of nitrate. A second similar experiment using $0,80,160,240,320 \mathrm{mg} \mathrm{N} / \mathrm{kg}$ medium and $1 \mathrm{mg} / \mathrm{kg}$ nitrapyrin showed no phytotoxic effects and also induced no significant changes in dry weight, tissue nitrogen content or residual medium nitrogen content regardless of nitrogen treatment. $\mathrm{N}$ concentration and $\mathrm{N}$ form effects were similar to previously reported research with an accumulation of nitrates in tissues with higher nitrate nutrition.

FERTILIZER RATES AFFECT YIELDS OF HIGH-DENSITY PLANTINGS OF BROCCOLI (BRASSICA OLERACEA)

R.P. Bracy*, R.L. Parish, P.E. Bergeron, and E.B. Moser, Louisiana State University Agricultural Center, Louisiana Agricultural Experiment Station, Hammond Research Station, 5925 old Covington Hwy., Hammond, LA 70403

A precision cultural system proved successful for growing broccoli in multiple rows of plants on narrow or wide beds. Higher production obtained from planting in the multiple-row configurations, however, was not proportional to the increase in number of rows. To quantify the optimum rate of fertilization on multiple rows per bed, broccoli was grown during the spring and fall, 1990, in one row/1-m beds, two rows $/ 1-\mathrm{m}$ beds, or six rows $/ 2-\mathrm{m}$ beds with fertilizer rates ranging from 448 to $1,680 \mathrm{~kg} \cdot \mathrm{ha}^{-}$of $9 \mathrm{~N}-12 \mathrm{P}-22 \mathrm{~K}$ and 150 to $560 \mathrm{~kg}^{-\mathrm{hg}^{-1}}$ of ammonium nitrate. During both seasons, fertilizer rate had an overall linear effect on the yieid but did not affect average head weight. Response to fertilizer rates was greatest when broccoli was grown in six rows $/ 2-m$ beds. Broccoli grown during the spring showed a greater response to fertilizer rates than did broccoli grown in the fall.
FERTILIZER MOVEMENT AND SALT ACCUMULATION AS AFFECTED BY IRRIGATION METHOD AND GROUND COVER IN MELON PRODUCTION

Robert Wiedenfeld* and Robert Stubblefield, Texas A\&M University Agricultural Research and Extension Center, Weslaco, TX 78596

Plastic mulch ground cover and drip irrigation have produced substantial increases in yield and earliness of melons. However, such practices affect water movement, and nutrient and salt distribution in the soil. Salt levels in the soil after a melon crop using drip or flood irrigation increased in bare soil but decreased where plastic mulch had been used. Apparently capillary rise of water in response to surface evaporation brought salts up into the root zone. Very little of the applied $\mathrm{N}$ was detectable at the end of the study. However, enhanced early vine growth due to $\mathrm{N}$ application where drip irrigated but not where flood irrigated indicated that flood irrigation may have caused earlier $\mathrm{N}$ losses. Yield responses to $\mathrm{N}$ regardless of irrigation method indicated that early availability may have been most important. Yield increases were found for drip vs flood irrigation, and for plastic mulch vs bare soil, both of which may have been earliness effects; but the later treatments did not get the chance to catch up due to the occurrence of vine decline.

ONION GROWTH AND NUTRIENT UPTAKE PATTERNS AS AFFECTED BY NITROGEN RATE AND TIMING OF APPLICATION

Robert Wiedenfeld, Texas A\&M University Agricultural Research and Extension Center, Weslaco, TX 78596

Onion production requires $\mathrm{N}$ fertilization, yet use efficiency of applied $\mathrm{N}$ is low. Improvements may be possible with a better understanding of plant growth and nutrient requirements over time. Onion growth and nutrient uptake was extremely slow during the winter months following planting, then increased substantially in the spring. Onion leaf $\mathrm{N}$ concentrations declined with age, while bulb $\mathrm{N}$ concentrations fluctuated with growing conditions but showed no longterm trend. Responses to $\mathrm{N}$ application were due primarily to timing and less to rate applied. Nitrogen uptake increased in some cases very quickly following $\mathrm{N}$ application, and in other situations was still evident after $6 \frac{1}{2}$ months. Yield increases, however, occurred only for preplant and winter fertilizer applications, not for spring application. Yield responses to both timing and rate varied by cultivar, with the later maturing cultivar doing best at the highest rate of preplant and the higher 2 rates of the winter applied $\mathrm{N}$ fertilizer.

\section{TOMATO FERTIGATION}

R. A. Straw and C. A. Mullins, Department of Plant and Soil Science, University of Tennessee, Plateau Experiment station, Rt. 9, Box 363, Crossville, TN 38555 .

Tomato trials with black plastic mulch, drip irrigation, and fertigation were conducted on a Lily sandy loam soil of medium fertility at Crossville, TN in 1990 and 1991. 'Mountain Pride' tomatoes were fertilized with a broadcast preplant application of $1120 \mathrm{~kg} \mathrm{ha}^{-1}$ of 10-4.4-8.3 fertilizer with and without combinations of black plastic mulch and weekly applications of $0.64 \mathrm{~cm}$ of water for 12 weeks through drip irrigation. Three black plastic mulch and drip irrigation treatments supplied additional nitrogen and potassium fertilizer through the drip irrigation system. Yields were increased by use of black plastic mulch and by trickle irrigation in 1991. However, additions of fertilizer through drip irrigation had no effect on yields.

SOIL APPLIED SULFATE IMPROVES VEGETABLE AMARANTH QUALITY D. J. MAKUS, USDA-ARS, BOONEVILLE, AR 72927

Sulfate, as $\mathrm{K}_{2} \mathrm{SO}_{4}$, was applied to silt loam (Leadvale) soils of $\mathrm{pH}$ of 5.0 and 7.1 at rates of $0,6,18$ and $36 \mathrm{~kg}$ $\mathrm{s} /$ ha. Nitrogen, as $\mathrm{NH}_{4} \mathrm{NO}_{3}$, was split applied at 0 and $120 \mathrm{~kg} / \mathrm{ha}$. A11 treatments received 55 and $45 \mathrm{~kg} / \mathrm{ha}$ of $\mathrm{P}$ and $K$, respectively. Twenty day-old plants of accession RRC 241 were transplanted on $12 \mathrm{July} 1990$ and harvested 47 days

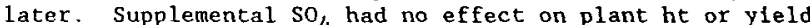
but increased soil solution $\mathrm{SO}_{4}$ levels at the end of the season. Leaf blade $\mathrm{N}$ and $\mathrm{S}$ levels were increased at the highest $\mathrm{SO}_{4}$ rate. Higher $\mathrm{SO}_{4}$ rates increased leaf blade chlorophyll (chloro) 'a', total chloro and total carotenoid 
levels. Response of leaf blade total sulfur, sulfate and organic sulfur to supplemental $\mathrm{SO}_{4}$ was linear. Organic to inorganic $S$ ratios were unchanged. Plants grown at $\mathrm{pH} 5$ had lower yields but higher leaf blade $\mathrm{K}, \mathrm{Al}, \mathrm{Fe}, \mathrm{Mn}, \mathrm{Zn}$ and $\mathrm{Cu}$ levels. Plants grown at $\mathrm{pH} 7$ had higher leaf blade $\mathrm{P}, \mathrm{Ca}$ $\mathrm{Na}$, and chloro levels. Soil pH did not effect soil solution $\mathrm{SO}_{4}$ levels. $\mathrm{N}$ reduced soil $\mathrm{pH}$, and leaf blade $\mathrm{P}, \mathrm{Ca}, \mathrm{Mg}$, $\mathrm{Zn}$ but increased soil electrolytes, leaf blade $\mathrm{N}, \mathrm{Na}, \mathrm{Mn}$, chloro ' $a$ ' and ' $b$ ', and total carotenoids. Leaf blade $N$ was the only leaf consituent from plants grown at both $\mathrm{pHs}$ correlated with leaf blade pigments.

\section{FATE OF NITROGEN FERTILIZERS AS AFFECTED BY RATE ANDSOURCEON AMARANTH.}

Kalala Mwamba*, E.G. Rhoden, R.O. Ankumah and V, Khan, Deptartment of Agricultural Sciences, Tuskegee University, Tuskegee, AL 36088.

Amaranth (Amaranthus sp.) is a vegetable crop with grains and leaves high in protein, especially, lysine and the sulfurcontaining amino acids which are limiting in many vegetables and grains. These nutritional qualities and the ease of growth make it a suitable alternate crop for limited resource farmers. A study was conducted to delermine the effect of nitrogen sources and fertilization rates on amaranth production in Alabama and other Southeastern States. The experiment was set up as a complete randomized block design in Norfolk sandy loam (Fine silicoeus, thermic, Typic Paleudult). Four nitrogen sources (urea, sodium nitrate, ammonium sulfate, and ammonium nitrate) were used at three different levels $(0,40$, and $80 \mathrm{Kg} / \mathrm{ha})$ one week after transplanting. Sources of nitrogen did not have any significant effect on both fresh and dry vegetable yield $(p \leq 0.05)$. However, fertilization brought significant increases in both yield and total nitrogen content of vegetable amaranth ( $p \leq 0.05)$.

CHLORINATION TO PREVENT CLOGGING IN MICRO-IRRIGATION SYSTEMS Steve Kovach*, Department of Horticulture, Larry Curtis and Jim Allen, Agricultural Engineering Department, Auburn University, Alabama 36849-5630

Irrigating with a micro-irrigation (drip) system offers improved crop quality and yield with significant savings of energy and water. To deliver these benefits reliably, a grower's system must include chlorination: or some other effective water treatment program to prevent clogging, the most cormon problem of micro-irrigation. Step-by-step procedures of chlorination of micro-irrigation systems are discussed. Injected into micro-irrigation systems, chlorine kills the micro-organisms--bacteria, fungi and algae--that may be in a water source and are the most cormon system cloggers.

\section{Floriculture \& Ornamentals}

\section{EPISODIC ROOT AND SHOOT GROWTH IN A WOODY} ORNAMENTAL

Jeff S. Kuehny* and Mary C. Halbrooks, Department of Horticulture, Clemson University, Clemson, SC 29634-0375.

Episodic growth is a term used to define alternate episodes of root and shoot growth. Fresh weight gain of Ligustrum japonicum roots and shoots was continuous through each episode of shoot elongation. Root:shoot ratio, however varied over time and oscillated with each episode of shoot elongation. During shoot elongation the percent fresh weight (of whole plant weight) allocated to the shoot decreased while the percent allocated to roots increased. During cessation of shoot elongation the percent fresh weight allocated to the shoot increased; while percent allocated to roots decreased. Formation of lateral roots was synchronous with shoot elongation.
EFFECTS OF UNICONAZOLE MEDIA DRENCH TREATMENTS ON WATER RELATIONS AND GROWTH OF 'LALANDEI'

\section{PYRACANTHA}

Robert M. Frymire* and Janet C. Cole, Department of Horticulture and Landscape Architecture, Okjahoma State University, Stillwater, OK 74078

Uniform rooted cuttings of pyracantha (Pyracantha coccinea M.J Roem. 'Lalandei') were potted into 3.8 liter containers in a pine bark:sand medium. Plants were treated with a medium drench at $0.5 \mathrm{mg}$ ai per container, or a foliar spray at $150 \mathrm{mg}$ ai per liter, or no uniconazole. Plants also were exposed to one of three irrigation regimes: nonstressed, stressed or acclimated. Uniconazole had little effect on leaf water potential, osmotic potential, transpiration or leaf conductance. The uniconazole drench treatments reduced plant growth and increased $\mathrm{N}, \mathrm{Ca}$, and $\mathrm{Mn}$ concentrations in the leaves. Foliar applications had less effect on plant growth and elemental content. Acclimated and stressed plants had lower water and osmotic potentials, transpiration rates and leaf conductance than nonstressed plants on the final day of the stress cycle. Acclimated plants had higher levels of $\mathrm{N}$ and $\mathrm{Mn}$ with lower levels of $\mathrm{Zn}$ in the leaves than either stressed of nonstressed plants.

EFFECT OF PACLOBUTRAZOL FORMULATION ON THE GROWTH AND FLOWERING OF BUDDLEIA DAVIDII 'DUBONNET'

John M. Ruter, University of Georgia, Department of Horticulture, Coastal Plain Experiment Station, Tifton, GA 31793

Granular and liquid formulations of paclobutrazol were tested to evaluate the growth and flowering response of butterfly bush (Buddleia davidii Franch. 'Dubonnet'). At the rates tested $(5,10,20$, and $40 \mathrm{mg}$ ai $\left.\cdot \operatorname{pot}^{-1}\right)$, the granular formulation reduced the growth index, plant height, shoot dry weight, total plant biomass, number of panicles and panicle length to a greater degree than the liquid formulation applied as a drench. Both formulations reduced total plant biomass and increased the root:shoot ratio compared to the control. All rates of the granular formulation above $5 \mathrm{mg}$ ai $\cdot$ pot $^{-1}$ produced non-marketable plants. Since no phytotoxicity was observed with any treatment, the application of paclobutrazol to control the growth of butterfly-bush may be useful if the correct formulation and rate of application are chosen.

DELAYED WILTING OF BEDDING PLANTS TREATED WITH HYDRETAIN

James E. Barreft ${ }^{*}$ and Terril A. Nell, Environmental Horticulture Department, University of Florida, Gainesville, FL 32611

Bedding plant seedlings were obtained as plugs from commercial sources, transplanted into $10-\mathrm{cm}$ pots, and grown using standard commercial procedures. When plants reached a marketable stage, they were treated with Hydretain, moved to a heavy shaded bench in the greenhouse, and time to first wilt was determined. At wilt, plants were given $180 \mathrm{ml}$ of water, and time to second wilt was observed. Hydretain was applied directly to the media in a volume of $90 \mathrm{ml}$ per pot. Hydretain dilutions in water were 1:4, 1:9, 1:14, 1:19, and 0:1 (controls). Time to first wilt in 'Red Elite' geraniums was $11,10,9,10$, and 5 days, respectively. For 'Little Bright Eyes' vinca, first wilt was in 7, 8, 5, 5, and 4 days; and time from treatment to second wilt was $18,14,11,10$, and 8 days, respectively. For 'Super Elfin Red' impatiens, first wilt was in 5, 4, 4, 3 , and 3 days; and the water absorbed was $121,167,172,132$, and $148 \mathrm{ml}$, respectively. Second wilt was in $7,7,8,5$, and 5 days, respectively.

RESULTS OF A TWO-YEAR STUDY ON POINSETTIA RESPONSE TO IRRIGATION WITH WATER HIGH IN SODIUM

John D. Griffin*. Peter W. Gallagher., and Kenneth W. Farrish, Louisiana Tech University, Ruston, LA 71272

Three cultivars of Poinsettia (Annette Hegg Lady, V-14 Pink, and Topwhite) were each treated with the same three concentrations of $\mathrm{Na}$ and $\mathrm{Ca}$, plus a Tap water and Distilled Water Control. Plants were evaluated for the following parameters: quality (bract diameter, height, foliar blemishes), dry weights (root and shoot), and $\mathrm{Na}$ and $\mathrm{Ca}$ contents (root and shoot). Postharvest keeping quality was evaluated in a subsequent study with the same cultivars and treatments

It was found that high levels of $\mathrm{Na}$ reduced bract size, height. and overall quality. Root tissue did accumulate $\mathrm{Na}$, but only to a certain level (approx. $300 \mathrm{~g} / \mathrm{kg}$ ). Shoot tissue continued to accumulate $\mathrm{Na}$ as 
concentration of $\mathrm{Na}$ increased in the irrigation water. $\mathrm{Na}$ accumulation in shoot tissue was approx. doubled in Topwhite when compared to V-14 Pink and Annette Hegg Lady. Postharvest keeping quality was not reduced by increased $\mathrm{Na}$ concentrations in irrigation water.

EVALUATION OF METHODS TO PREVENT ROOT GROWTH INTO CAPILLARY MATS

Guoqiang Hou', Jack W. Buxton and Donna Switzer, Department of Horticulture and Landscape Architecture, University of Kentucky, Lexington KY 40546.

To prevent rooting into an irrigation mat, five water porous materials, perforated black plastic, perforated ground cover, polyester, woven polypropylene and porous plastic, were evaluated as mat covers. Only polyester, woven polypropylene and porous plastic prevented penetration of roots of marigold seedlings into the mat. Under high moisture stress, root tips were killed at the cell drainage hole; however, under low moisture stress the roots formed a mat on top of these mat covers. To prevent root penetration out the drainage hole, polyester and porous plastic were glued over the hole. No difference in shoot growth was observed between the control (only polyester mat cover) and seedlings produced in drainage hole covered cells. Total root growth of plug seedlings with drainage hole covered were greater than the control. Ten days after transplanting, seedlings that had been produced in plugs, with covered drainage holes, were larger.

\section{PLANT EVALUATION AND INTRODUCTION AT THE TSU-} MCMINNVILLE NURSERY RESEARCH STATION

Willard T. Witte*, Scott Schlarbaum', Roger Sauve2. Phillip C. Elanagan', Department of Ornamental Horticulture and Landscape Design \& 'Department of Forestry, Wildlife and Fisheries, University of Tennessee, Knoxville, TN 37901-1071; ${ }^{2}$ CARP, Tennessee State University, Nashville, TN 37209-1561

Since 1988, efforts have been underway to establish a nursery research station in McMinnville, Warren County, Tennessee. Approximately 80 acres of farm property adjacent to the Collins scenic river has been conveyed to Tennessee State University (TSU) for this purpose. Scientists at TSU, Tennessee Technological University, University of Tennessee, and USDA's National Arboretum and Shade Tree Laboratory have cooperated in obtaining grant funds via the Capacity Building Grants Program to initiate a plant evaluation and introduction program. Replicated trials of woody genera include Acer, Castanea, Comus, Lagerstroemia, Quercus, Syringa, Ulmus. Herbaceous genera are Echinacea, Hemerocallis, Hosta. Plantings will he made over a three year period as infrastructure at the new station develops. Additional grant proposals have been recently submitted.

SEVERAL NEW SPECIES OF MIRABILIS, THEIR MERIT AS ANNUAL OR PERENNIAL LANDSCAPE PLANTS, Alice (Jack) Le Duc, Department of Botany, University of Texas, Austin, TX 78713 .

Several collecting trips in Mexico, in assoctation with a monographic revision of a portion of the genus Mirabllis, have produced several spectes which show promise as new perennial landscape plants. Mirabilis pringle1 Weatherby, with 1 ts showy pink flowers, has potential as a striking summer blooming plant, particularly when used as a container accent plant. Equally promising are two as yet unnamed specles, their fragrant white flowers opening in the evening, seem ideal as terrace or patio accents.

LANDSCAPE ARCHITECTS AND THE DEMAND FOR PLANT MATERIAL Melvin $P$. Garber, Department of Horticulture. The University of Georgia, P0 Box 1209, Tifton, GA 31793

Landscape architects occupy a strategic position in the landscape industry; yet, they. have not been generally considered an important customer group by nurserymen. They influence selection of plant material for commercial, government, and residential landscapes and are generally the first to know what will be in demand. A recent survey of Georgia landscape architects found they specify $\$ 85 \mathrm{M}$ of plants. This compares to the $\$ 200 \mathrm{M}$ estimate for the 1989 wholesale value of nursery stock produced in Georgia. In addition, $60 \%$ of the landscape architectural firms influence which production nursery supplies plants by determining or recommending the production nursery where the landscape contractor obtains plants. More importantly, $92 \%$ of the large firms, which account for $67 \%$ of the doliar value, are involved in selection of the production nursery. The results provide the first quantitative estimate of the influence of landscape architects on nurserymen and suggest that nurserymen should view landscape architects as important customers.
COMPUTER COST ESTIMATOR FOR LANDSCAPE INSTALLATION Gary L. Wade ${ }^{\star}$ and William A. Thomas, Horticulture and Agricultural Economics Departments, respectively, The University of Georgia, Athens, GA 30602 Cost estimating and job bidding are among the most complex and time-consuming tasks of landscape professionals. A software package was developed to make cost estimating more accurate and efficient. HORT LAND, computer cost estimator for landscape installation, was developed for IBM compatible PC's using SuperCalc 5 spreadsheet soltware. The user builds a series of data bases, including an items listing of materials and equipment utilized in his operation along with their associated cost. Then, he defines a series of generic tasks, such as planting a 1 -gallon size plant, and refers to the previous items list and associated code numbers for the materials and equipment necessary to install the plant. Once these initial data bases are constructed and saved, the user inputs a plant list, including size and price, then instructs the computer to translate the appropriate data from the initial data bases to arrive at a detailed listing of costs. The program then computes direct job cost and bid price, including overhead and profit.

ATTITUDES AND PERCEPTIONS OF CHOOSE-AND-CUT CHRISTMAS TREE CONSUMERS

Malgorzata A. Florkowska ${ }^{1}$, Orville $M$, Lindstrom ${ }^{1}$, and Wojciech $\mathrm{J}$. Florkowski ${ }^{2}$, ${ }^{1}$ Department of Horticulture and ${ }^{2}$ Department of Agricultural and applied Economics, University of Georgla, Griffin, GA 30223.

A survey was conducted to investigate consumer preferences in a Christmas tree purchase. The survey asked about consumers' socioeconomic status, customer loyalty and on farm buying habits, specific tree preferences, and preferences of Iive versus artificial trees. Fifty-three percent of the 148 respondents were male and $61 \%$ were between the ages of 25 44. Thirty-three percent had 3 children, sox were college graduates and $59 x$ had a family income greater than $\$ 35,000$. Sixty-eight percent purchased their tree at the same farm as they did the previous year, $62 \%$ traveled from $1-10 \mathrm{miles}$ to the farm, 50\% of trees were purchased by December 8 , and $70 \%$ of the purchases were during the afternoon. The most common tree selected was a 6-7 ft. Virginia Pine and selection time ranged from 5-30 minutes. Compared to an artificial tree, respondents cited messiness, difficulty to carry and trouble to remove as major drawbacks of choose-and-cut Christmas trees. This was particularly evident in female and elderly respondents.

\section{Postharvest \& Biotechnology}

POSTHARVEST BEHAVIOR OF GREEN AND WHITE ASPARAGUS $A, R$. Gonzalez*, T. Wang, D.J. Makus and A. Mauromoustakos, Department of Food Science, University of Arkansas, Fayetteville, AR 72703

Respiration and quality changes were measured in white and green asparagus stored at $20^{\circ} \mathrm{C}$. Green asparagus had a higher respiration rate and weight loss than white. Respiration rates decreased and stabilized after 2 days storage in both green and white asparagus. Total phenolics and pulp pH were higher in green than in white asparagus. No significant difference was observed in titratable acidity. Total phenolics and $\mathrm{pH}$ decreased while titratable acidity increased during storage of both types of asparagus. Ascorbic acid levels were higher in green spears but soluble solids were higher in white spears. Both ascorbic acid and soluble solids decline during storage. Total chlorophyll content of green asparagus decreased during storage. White asparagus had little chlorophyll. Green color, measured by $\mathrm{CDM}-\mathrm{a}$ values, followed the same pattern as total chlorophyll.

\section{WATER VAPOR TRANSMISSION RATES OF CELGARD ${ }^{\circledR}$ D-304} MICROPOROUS, POLYPROPYLENE FILMS

Laura Dellevigne, Peter Vergano, Lee Wiles. Andy Hale and Jeff Adelberg. Department of Food Science/Horticulture, Clemson University, Clemson, SC 29634

Commercially produced membrane rafts containing Celgard D-304 microporous, polypropylene film are used to support the growth of micropropagated plants in liquid media. This method is used because growth experiments using membranes resulted in plant growth rates equal to or greater than those grown on agar. Inconsistent results of plant growth 
on these rafts led to an interest in measuring the water vapor transmission rates (WVTR) of the membranes. A modified WVTR test (ASTM E96-80) was used on $15 \mathrm{raft}$ samples. Results showed that the supplier's value of $49.2 \mathrm{~g} / \mathrm{m}^{2} \cdot \mathrm{hr}$ falls within the range of measured values of 39.2 to 54.8 $\mathrm{g} / \mathrm{m}^{2} \cdot \mathrm{hr}$. Inconsistencies in growth of micropropagated plants may not be due to variability in the WVTR of the Celgard film. It is possible that the WVTR of the film is not the most important factor in facilitating liquid nutrient transport across the membrane. Other properties of the film need to be measured to determine factors affecting growth rates observed.

\section{PACKAGING AND STORAGE OF WATERMELON USING DIFFERENT SHRINK-WRAP FILMS \\ Noida A. Biglete*. Robert F. Testin and James W. Rushing, Department}

of Horticulture/Food Science, Clemson University, Clemson, SC 29634

A triploid watermelon cultivar, 'Crimson Trio' and a seeded cultivar, 'Mirage', were shrink-wrapped in four different films: Cryovac D940, Cryovac D955, and Magellan film with and without a blended biocide. Unwrapped fruits served as the control. Fruits were stored at either $1.5,10$ and $21^{\circ} \mathrm{C}$ for three weeks plus an additional week at $21^{\circ} \mathrm{C}$ to simulate retail marketing. Total soluble solids (TSS) and pulp color measurements were taken after harvest and at the end of the storage period while weight, disease incidence, chilling injury and visual quality rating were monitored at weekly intervals. Results showed that the seedless variety have better postharvest qualities in terms of storage life, TSS and chilling resistance than the seeded variety. Wrapped fruits had less weight loss, higher TSS and better rind color than the unwrapped fruits at the end of the storage period. However, all wrapping treatments, including the biocidal film increased disease incidence compared to unwrapped controls. Also, wrapping did not alleviate chilling injury, which was most severe in fruits stored at $1.5^{\circ} \mathrm{C}$ and then held at $21^{\circ} \mathrm{C}$ for one week.

\section{Posters}

EVALUATION OF POD DETACHMENT FORCE IN SOUTHERNPEA

Blair Buckley* and Katharfne Pee, Calhoun Research Station, Louistana Agricultural Experiment Station, LSU Agricultural Center, Calhoun, LA 71225

Ease of pod detachment is an Important consideration when selecting cultivars for mechanical harvest at the mature-green stage. Sixteen southernpea cultivars and breeding lines were evaluated for pod detachment force. The cultivars varied in pod detachment force. $M N-13$ had the largest detachment force with a measurement of $2.18 \mathrm{~kg}$. Royal Cream had the smallest detachment force with a measurement of $1.2 \mathrm{~kg}$. Pod length, pod diameter, pod weight, basal pod fill, and length of peduncle synapse was recorded for each pod sampled for detachment force. There was no clear association between pod detachment force and the five traits.

VEGETABLE AMARANTH PERFORMANCE AT DIFFERENT SOIL MOISTURE LEVELS

Wayne F. Whitehead and Bharat P. Singh, Agricultural Research Station, Fort Valley State College, GA 31030-3298

The effects of differing soil moisture levels on the vegetative components of vegetable amaranth, Amaranthus tricolor RRC no. 241, were evaluated. A completely randomized design with 10 replications and 4 treatments $(3,6,13, \& 18 \%$ soil moisture) was followed. Leaf, stem, plant, root fresh weight and leaf area (LFW, SFW, PFW, RFW, and LA, respectively)-were recorded 48 days after planting. For each of the vegetative components the only significant difference $(P \leq 0.05)$ occurred between $3 \%$ versus $6-18 \%$ soil moistures, with moisture level of 6-18\% showing no significant variation among themselves. The mean ranges for LFW (28.3-32.7 g), STW (6.9-9.2 g), PFW (41.3-48.2 g), RFW (8.6-12.8 g), and LA (1049-1222 $\left.\mathrm{cm}^{2}\right)$ across $6-18 \%$ soil moisture were approximately four times greater than the vegetative components of $3 \%$ soil moisture. From these preliminary results, it appears that vegetable amaranth has the ability to grow and perform well over a 6$18 \%$ soil moisture range, indicating an ability to better adjust and adapt to changing soil moisture environments.
LOW GIBBERELLIN ENHANCED SWEETPOTATO PLANT PRODUCTION Melvin R. Hall, Department of Horticulture, University of Georgla Coaetal plain Experiment station, P. O. Box 748, Tifton, Georgia 31793

Immersion of sweetpotato [Ipomoea batatas (L.)] storage

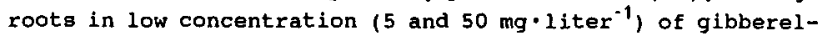
lic acid (GA) in solutions of benzyl adenine plus $\mathrm{GA}_{4+7}$ increased early but not total plant production from bedded roots of 'Georgia Jet' and 'Jewel'. Immersion in 0.5 and $1 \mathrm{mg} \cdot{ }^{\prime}$ iter $^{-1}$ solutions of $\mathrm{GA}_{3}$ increased early plant production from 'Georgia Jet'. Nelther weight nor visual appearance of the harvested plants nor root yield from transplants were influenced by gibberellin treatments of the bedded roots.

\section{SWEET CORN HERBICIDES}

R. A. Straw and C. A. Mullins, Department of Plant and Soil Science, University of Tennessee, Plateau Experiment Station, Rt. 9, Box 363, Crossville, TN 38555 .

'Merit' and 'silver Queen' sweet corn plants were treated with nicosulfuron and primisulfuron herbicides at rates of 0.035 and $0.039 \mathrm{~kg} \mathrm{ai} \mathrm{ha-1}$, respectively. These herbicides were applied either over the top postemergence or directed post emergence. over the top postemergence applications killed all of the 'Merit' plants, but did not injure 'Silver Queen' plants. All treatments provided greater than $90 \%$ control of johnson grass and fall panicum.

In a separate experiment, 'silver Queen', 'Incredible', 'How Sweet It Is', 'Pinnacle', 'Sweetie $76^{\prime}$ ', and 'Landmark' showed slight injury, while 'Silverado' showed moderate injury 2 weeks after application of a postemergence treatment of either nicosulfuron or primisulfuron. However, the plants soon outgrew this injury and yields were not reduced due to herbicide treatments.

\section{SNAP BEAN FERTIIIZATION}

C. A. Mullins and R. A. Straw, Department of Plant and Soil Science, University of Tennessee, plateau Experiment station, Rt. 9, Box 363, Crossville, TN 38555 .

'Blue Ridge' snap beans were planted with no fertilizer or banded rates of $560^{\mathrm{kg} \mathrm{ha}}$ of a 10-4.4-8.3 fertilizer on solls with medium fertility in 1990 and 1991. Foliar applications of water soluble fertilizers containing nitrogen, phosphorus, and potassium were made at early bloom and in split applications at early bloom and repeated 10 days later. No response to fertilizer banded at planting or to foliar nutrient applications was found in snap bean yields or pod quality. Most fertilizer applications at planting increased plant size and lodging in 1990, but not in 1991. With the use of a rotation schedule and winter cover crops, snap beans showed no response to fertilization on soils of medium fertility.

BETTERGRO BLACKEYE: A NEW PEST AND DISEASE RESISTANT HIGH YIELDING SOUTHERNPEA

R. L. Fery* and P. D. Dukes, U. S. Vegetable Laboratory, ARS, USDA, 2875 Savannah Highway, Charleston, SC 29414

The Agricultural Research Service of the United States Department of Agriculture announced the release of 'Bettergro Blackeye' southernpea on $24 \mathrm{July} 1991$. The new cultivar is we11 adapted for production throughout the southern United States where it can be expected to produce excellent yields of high quality, blackeye-type peas. 'Bettergro Blackeye' outyielded the 'Pinkeye Purple Hull-BVR' check in the 1986, 1987, 1988, and 1989 Regional Southernpea Cooperative Trials by $34.8,14.3,12.6$, and $20.9 \%$, respectively. Canned samples of fresh 'Bettergro Blackeye' peas scored well in three years of quality evaluation tests. The new cultivar is resistant to the cowpea curculio, the major insect pest of the southernpea in southeastern production areas, and root knot, a severe root disease Incited by several species of the root-knot nematode. 'Bettergro Blackeye' plants have a greater tendency to produce a second crop than plants of most southernpea cultivars. 
BETTERGREEN: A NEW, CREAM-TYPE SOUTHERNPEA WITH GREEN COTYLEDONS

R. L. Fery*, P. D. Dukes, and F. P. Maguire, U. S. Vegetable Laboratory, ARS, USDA, 2875 Savannah Highway, Charleston, SC 29414

The Agricultural Research Service of the United States Department of Agriculture announced the release of 'Bettergreen' southernpea on $30 \mathrm{Apr} 11$ 1991. 'Bettergreen' is a cream-type cultivar that is homozygous for a newly discovered gene(s) conditioning a unique green cotyledon trait. 'Bettergreen' can be harvested at the near-dry seed stage of maturity without loss of the seed's fresh green color. The color of the peas harvested upon reaching "dry-stage" maturity is light olfve, and the color is present in both the seed coat and the cotyledons. The fresh peas are small ( $22 \mathrm{~g}$ per 100 peas), ovate to reniform in shape, and have excellent culinary quality. The dried peas have a smooth seed coat. 'Bettergreen' is recommended for use as a home garden and fresh market cultivar for spring, mid-season, and fall plantings throughout the southeastern United States. It is particularly recommended for trial as a commercial processing cultivar for the frozen food industry.

USING A GEOGRAPHIC INFORMATION SYSTEM (GIS) TO CHARACTERIZE AND TO MAP GROWING SEASONS FOR VEGETABLES

Joanne Logan and David L, Coffey, Department of Plant and Soil Science, University of Tennessee, Knoxville, TN 37901. Vegetable production has become a multi-million dollar activity in Tennessee. The large number of options of planting dates and maturity classes of different vegetable species and cultivars result in a flexible, yet confusing. situation for the grower. A plentiful supply of vegetables for the processor, fresh market, or family table can be assured by the proper scheduling of planting and harvest of different crops and cultivars. Growers have very limited access to climatic data oriented to vegetable production in their locations. For the most part, they depend on planting maps on the backs of seed packets, or on extension bulletins with very general planting and harvest date recommendations. Tennessee consists of 4 climatic divisions that do not adequately describe the multitude of climates due to the diverse topography. The objective of this research was to create GIS maps of climatic variables important to vegetable production. Maps of temperatures, growing degree days, and rainfall, freeze and heat stress probabilities based on data from 72 locations in Tennessee were used to characterize the growing seasons for different vegetables.

GROWTH RESPONSES OF WATERMELON ON WAVELENGTH SELECTIVE MULCHES ANO VISPORE ROW COVER IN MISSOURI

Mack A. Wilson* and Victor A. Kahn, Department of Agriculture, Southeast Missouri State University, Cape Girardeau, M0 63701 and George Washington Carver Agricultural Experiment Station, Tuskegee University, Tuskegee, AL 36083.

The influence of Vispore row cover and four synthetic mulches on the growth and yield of watermelons were studied. Row cover and synthetic mulch treatments consisted of Vispore row cover, IRT-76 (green), AL-OR (brown), clear and black polyethylene mulches. Vispore was used with a combination of four mulches and two controls (Vispore alone and bare soil). Significant differences were observed by orthogonal comparison when no row cover (NRC) was compared to row cover (RC) on the number '000/acre of marketable "Crimson Sweet' watermelons. Total, marketable and percent marketable yields were significantly different when orthogonal comparison were performed on NRC vs. RC. Yields were greater when RC vs. NRC treatments were used on 'Crimson Sweet' watermelons.

\section{SENSITIVITY OF WATERMELON PLANT GROWTH TO}

PHOTOMORPHOGENIC SIGNALS DURING THE LIGHT OR DARK PHASE OF THE PHOTOPERIOD

Heather, H. Friend*, Arne Szebo, and Dennis R. Decoteau, Department of Horticulture, Clemson University, Clemson, SC 29634-0375

Previous research has demanstrated that watermelon piants are sensitive to changes in light quality, as suggested by an individual treatment of plants with 15 -min of end-of-day (EOD) red (R)and far-red (FR) light. FR-Induced growth responses (i.e., petiole elongation, internode elongation, reduced petiole angles) were reversed by immediately following the FR light treatment with $R$ light implicating phytochrome as the light quality perception mechanism. The objective of the present experiment was to determine the Influence of Individual and multiple FR light treatments (each treatment of $15-\mathrm{min}$ duration) during the light and dark phase of the photoperiod on photonorphogenic growth responses of young watermelon plants. Light regulated growth responses of watermelon were influenced by the timing and the number of light quality exposures during the light or dark phase of the photopertod. Individual FR treatments during the light phase except for the EOD exposure did not affect plant growth responses. In contrast, Individual FR trealments at selected intervals during the dark period affected plant development. The most effective individual FR treatment to induce growth responses was at the beginning of the dark perlod, with decreasing responses as the FR treatment was delayed Into the dark period. Multiple exposures of FR during the dark slightly increased growth responses as compared to a single EOD FR treatment.

GROWTH AND YIELD RESPONSES OF TRIPLOID WATERMELONS TO FERTILIZER SOURCE AND RATE, MULCH, AND ROW COVER D. R. Earhart*, M. L. Baker, and F. J. Dainello, Texas Agricultural Experiment Station, Overton, TX 75684

In a field experiment, fertilizer source (poultry litter vs. commencial) plastic mulch, row cover, and fertilizer rate (residual from 1990 study vs. additional) were applied in factorial combinations to determine the effect on vegetative growth and production of triploid watermelons. Litter (3.12\% total $\mathrm{N})$ was re-applied at the rate of $13.2 \mathrm{Mt}^{-h^{-1}}$ along with commercial fertilizer $(6 \mathrm{~N}-10.5 \mathrm{P}-20 \mathrm{~K})$ at $1.1 \mathrm{Mt} \cdot \mathrm{ha}^{-1}$. Plastic mulch showed the greatest influence on vegetative growth and production variables by increasing vine length $26.1 \mathrm{~cm}$. leaf area $61.8 \mathrm{~cm}^{2}$, yield $4207 \mathrm{~kg} \mathrm{ha}^{-1}$, melon number $741 \mathrm{ha}^{-1}$, and average melon weight $0.8 \mathrm{~kg}$, over unmulched plots. Plastic mulch with or without row cover increased melon number significantly when compared to plots without mulch or row covers. Poultry litter increased vine length, yield, and average melon weight $15.4 \mathrm{~cm}, 1971 \mathrm{~kg} \cdot \mathrm{ha}^{-1}$, and $0.5 \mathrm{~kg}$, respectively, when compared to commercial fertilizer. Poultry litter in combination with row cover increased yicld by $3864 \mathrm{~kg} \cdot \mathrm{ha}^{-1}$ over commercial fertilizer with row cover, and approximately $2567 \mathrm{~kg} \cdot \mathrm{ha}^{-1}$ over poultry litter and commercial fertilizer without row cover. Additional fertilizer increased average melon weight $1.3 \mathrm{~kg}$

\section{LOCALLY OBTAINED WATERMELON TRANSPLANTS OUTPERFORM} FLORIDA TRANSPLANTS IN ARKANSAS FIELD TRIALS

Tina Gray Teaque*, Arkansas State University, State University, AR 72467

Four week old watermelon (cv. Royal Sweet) transplants were obtained from long distance (FL) and local (AR) commercial transplant growers and set in plots in a commercial watermelon field near Leachville AR. Transplants (plugs) from AR (Burton's Inc., Tupelo, AR) were grown in inverted pyramid, Todd Flats (model 100A; 5/8" length X 1/2" width X 3" height) (Speedting Inc., Sun City, FL). FL transplants (LaBelle Plant World, LaBelle, FL) were grown in 1.5" square cells, 2" deep. All transplants were delivered 15 April and set on 16 April. Transit time for local transplants was $<2$ hrs, and plants were delivered in original flats. FL transplants were shipped on 14 April and were in transit ca. $28 \mathrm{hrs}$. They had been pulled from trays and were shipped in cardboard boxes. Plot size was 6 beds, $53.3 \mathrm{~m}$ long with treatments arranged in a RCB with 4 replications. Bed spacing was $2.9 \mathrm{~m}$ with between plant spacing of $1.5 \mathrm{~m}$. Data were subjected to ANOVA with mean separation by LSD

Plots were harvested 3, 8, 15 and 22 July. Total number of fruit produced from plots planted with AR transplants was greater than FL treatment plots in the first 3 of 4 harvests; significantly higher total cumulative yield was observed with AR compared to FL Iransplants $\left(45,115\right.$ and $35,172 \mathrm{~kg} \mathrm{ha}^{-1}$. respectively). Increases in-yield and earliness resulted in an increase in gross profit of $\$ 1225 \mathrm{ha}^{-1}$ for local transplants (based on national price data from that time period). No differences in average weights of fruit were observed for any harvests. Results indicate that Mid-South watermelon producers could benefit from utilizing locally grown transplants if plants are of comparable quality to those available from distant suppliers.

\section{-INFLUENCE OF THREE MULCHING SYSTEMS ON VEGETABLE YIELD AND SOIL LOSS UNDER HIGHLY ERODIBLE CONDITIONS}

Matthew Byers* . George Antonious and Keenan Bishop,

Community Research Service, Kentucky State University, Frankfort,

KY 40601

Using USLE standard plots, on 10\% slope, on uniform Lowell silt loam soil, the influence of three soil treatments and two representative vegetable crops on soil runoff losses was determined Yields (1990 and 1991) for each crop $\mathrm{x}$ soil treatment combination were also determined. Soil losses were determined by catching runoff, filtering, air drying and massing representative samples. With total volume per plot known, grams sediment per liter runoff were converted to $\mathrm{kg} / \mathrm{ha}$. Overall mean yields of pepper were 2.9 4.7, and 3.7 and pumpkin were $47.3,87.1$ and $76.1 \mathrm{~kg} / 7.3$-m row, respectively. Mean sediment losses over five rainfall events in 1991 in peppers were 52,1158, and 5362; and in pumpkins were 72, 3011, and $7271 \mathrm{~kg} / \mathrm{ha}$, for fescue, plastic and no-mulch treatments, respectively. Clearly, fescue in .6-m strips between rows, with comparable yields demonstrated (1991) and negligible sediment losses, was the best management practice (BMP). 
EFFECT OF ROOT LENGTH AND SPACING ON ESTABLISHMENT OF BLACKBERRY PLANTS

Blatr Buckley*, John R. Clark ${ }^{1}$, K.C. Pee, and Charles E. Johnson, Calhoun Research Station, Loulsiana Agricultural Experiment Station, LSU Agricultural Center, Calhoun, LA 71225, Univeristy of Arkansas Fruit Substation, Clarksville, AR 72830

Field tests at two locations examined the fnfluence of length and spacing of root propagules on blackberry plant establishment. Root propagules $10.2 \mathrm{~cm}$ long spaced $61 \mathrm{~cm}$ resulted in greater emergence, plant stand, and shoot growth than $5 \mathrm{~cm}$ and $2.5 \mathrm{~cm}$ root propagules. Differences in emergence and shoot growth between $10.2 \mathrm{~cm}$ progagules spaced $61 \mathrm{~cm}$ and $5 \mathrm{~cm}$ propagules spaced $61 \mathrm{~cm}$ were non-significant. Greenhouse tests compared four lengths of root propagules $(15.2 \mathrm{~cm}, 10.2 \mathrm{~cm}, 5 \mathrm{~cm}, 2.5 \mathrm{~cm})$ for production of nursery. plants. Percent emergence, time of emergence, and number of shoots per propagule produced from $2.5 \mathrm{~cm}$ propagules were comparable to results from $15.2 \mathrm{~cm}$ and $10.2 \mathrm{~cm}$ propagules.

\section{BREEDING FOR RESISTANCE TO ROSETTE (DOUBLE BLOSSOM) DISEASE} IN BLACKBERRY

Creighton L. Gupton*, USDA-ARS Small Fruit Research station, Poplarville, MS 39470 Crosses between 'Humble' and five other blackberry cultivars were made to determine the efflcacy of 'Humble' as a source of resistance to rosette (incited by Cercosporella rubi). Seven cultivars and three selections were planted at a disease free location and at a location where rosette is known to occur to determine the effect of double blossom on yield, berry weight, and ripening date. 'Cheyenne' $\mathrm{X}$ 'Humble,' 'Humble' $X$ 'Brazos,' and 'Navaho' X ('Humble' X 'Brazos') produced progenles with various levels of resistance. Promising selections were made from the latter two crosses. Genotype $X$ location interaction was significant for $y i e l d$ and not significant for either Julian date of 508 ripe fruit or weight per berry. These results suggest that rosette reduces yield but has little if any effect on weight per berry or ripening date. 'Shawnee' and 'Choctaw' were the highest yielding cultivars under disease free conditions; however, their yields were low in the test where they were infected with rosette. 'Brazos,' 'Choctaw,' and 'Rosborough' were the earliest ripening and 'Navaho' was the latest ripening cultivar.

NITROGEN FERTILIZATION AFFECTS MUSCADINE GRAPES

James M. Spierst and John H. Braswel1, USDA-ARS Small Fruit Research Station, Poplarville, MS and Mississippi

Cooperative Extension Service, Poplarville, MS 39470.

Leaf concentrations of $N, P, K, F e$, and $M n$ in

'Sterling' muscadine grapes (Vitis rotundifolia Michaux)

grown for 2 years in sand culture were not influenced by

different $\mathrm{N}$ fertilizer sources. Leaf $\mathrm{Zn}$ and $\mathrm{Cu}$ were higher

in plants receiving $\mathrm{N}$ as $\mathrm{NH}_{4} \mathrm{NO}_{3}$ rather than as

$\left(\mathrm{NH}_{4}\right)_{2} \mathrm{SO}_{4}$. Growth was greatest in plants fertilized

with $\mathrm{NH}_{4} \mathrm{NO}_{3}$ compared to those with either

$\left(\mathrm{NH}_{4}\right)_{2} \mathrm{SO}_{4}$ or $\mathrm{NaNO}_{3}$ fertilization. Leaf $\mathrm{Ca}, \mathrm{Mg}, \mathrm{Mn}$, and $\mathrm{Cu}$ content decreased linearly and leaf $\mathrm{N}$ increased linearly as $\mathrm{N}$ fertilizer rates were raised from 1.8 to 16.1 $\mathrm{mM}$. Plant growth was a positively correlated with leaf $\mathrm{N}$ but was negatively correlated with leaf $\mathrm{Ca}, \mathrm{Mg}$, and $\mathrm{Mn}$ content. Percent $\mathrm{Mg}$ in the leaves was reduced when $\mathrm{N}$ leve1s, regardless of $\mathrm{N}$ source, were raised from the low $(1.8 \mathrm{mM})$ to middle $(5.4 \mathrm{mM})$ rate. High leaf $\mathrm{N}$ levels were correlated with lower $\mathrm{Ca}$ and $\mathrm{Mg}$ in the leaves, indicating a possible relationship between $N$ fertilization and the late-season $\mathrm{Mg}$ deficiency often observed in muscadine grapes

TRAINING SYSTEM AFFECTS PERFORMANCE OF TABLE GRAPE CULTIVARS Dwtght Wolfe* and Gerald R. Brown, Department of Horticulture, University of Kentucky Research \& Education Center, P. 0. Box 469, Princeton, KY 42445

Each of the grape cultivars [Vitis species, (L) Batch], 'Concord', 'H1mrod', 'Challenger', 'Reliance', 'Glenora', 'Moored', planted June 1983, and 'Mars' planted Spring, 1987, was trained to the 4-cane Kniffin (KN) and the Geneva Double Curtain (GDC) systems. Yield per vine, pruning weight, number of nodes, cluster weight, number of berries per cluster, berry weight, and percent soluble solids were recorded. Vines from 'Reliance' trained to the KN system produced fruit with significantly higher percent soluble solids than did vines trained to the GDC. No significant differences in percent soluble solids were observed between the two training systems for the other cultivars. 'Concord' produced more $\mathrm{kg} / \mathrm{vine}$ of pruning weight when trained to the $\mathrm{KN}$ system than when trained to the GDC. Pruning weight did not differ significantly between the two training systems for the other cultivars. Cultivars more productive (yield/vine) on the GDC trellis were 'Concord', 'Himrod', 'Rellance' and 'Moored' whereas 'Cha1lenger' was more productive when vines were trained to the KN system. No differences between the two training systems were observed for 'Glenora' or 'Mars'.

\section{ALKALINE WATER ACIDIFICATION INFLUENCES SODIUM UPTAKE BY AZALEA}

E. W. Bush* M. L. Robbins, and D. A. Wall, Department of Horticulture, Louisiana State University, Baton Rouge, LA 70803

Sodium bicarbonate type irrigation water is detrimental to the growth of Azalea indica 'Formosa'. Alkaline irrigation water reduced both top and root growth of 'Formosa' azalea. Leaf tissue sodium was significantly greater in azalea plant tissue irrigated with alkaline water. Concentrated sulfuric acid was used to acidify the alkaline water source. Acidification significantly reduced the uptake of sodium into the leaf tissue by $45 \%$. Leaf tissue $\mathrm{Ca}$ and $\mathrm{Mg}$ levels were significantly greater from plants irrigated wtih deionized water. Azalea plants irrigated with acidified water produced significantly better quality plants. Leaf and root tissue samples were taken after 8 months.

IRRIGATION METHOD AND MEDIA EFFECTS ON AGERATUM GROWTH AND CONTAINER LEACHATE

D.C. Fare ${ }^{\star}$, C.H. Gilliam, G.J. Keever, and R.B. Reed, 36849

The effects of overhead pulse irrigation versus conventional overhead irrigation on growth of Ageratum houstonianum 'Blue Puff' in 2 media, container leachate volumes and leachate $\mathrm{NO}_{3}-\mathrm{N}$ and $\mathrm{NH}_{2}-\mathrm{N}$ levels were evaluated. Container leachate volumes, and $\mathrm{NO}_{3}-\mathrm{N}$ and $\mathrm{NH}_{4}-\mathrm{N}$ levels were higher with pinebark: sand medium. Container leachate volumes tended to be lower with pulse irrigation compared to conventional irrigation. Shoot dry weights of plants grown in pinebark:peat were greater under conventional irrigation compared to pulse irrigation; however, growth indices, flower number, and $\mathrm{NO}_{3}-\mathrm{N}$ and $\mathrm{NH}_{4}-\mathrm{N}$ levels were not affected by irrigation method in either medium.

CONTROLLING HEIGHT AND FLOWERING IN HYPOESTES PHYLLOSTACHYA Chi Wang and Kevin L. Grueber*, Department of Horticulture, Virginia Polytechnic Institute and State University, Blacksburg, VA 24061.

Control of plant height and flowering are two major problems associated with the production of Hypoestes phyllostachya Bak. (polka-dot plant). In seed-propagated cultivars, sprays of ancymidol (A-Rest), chlormequat (Cycocel), paclobutrazol (Bonzi), and uniconazole (Sumagic) were effective in inhibiting shoot growth and internode elongation at $100,1000,33$, and $10 \mathrm{mg}^{\circ} \mathrm{l}^{-1}$, respectively. Daminozide (B-Nine), even at $6000 \mathrm{mg}^{-1} \mathrm{l}^{-1}$, was ineffective compared to untreated controls. Ethephon (Florel) was effective in retarding plant growth at $500 \mathrm{mg}^{-1}$, but at $1500 \mathrm{mg}^{-1}$ resulted in leaf distortion and horizontal shoot growth.

H. phyllostachya was determined to be a quantitative (facultative) short day plant. Seed-propagated plants with 16 or more nodes flowered regardless of photoperiod, bu flowering was more rapid under short days (SD) than under long days (LD). Application of ethephon significantly inhibited shoot elongation and number of flower buds formed and also increased the incidence of flower bud abortion. In seed-propagated plants, $500 \mathrm{mg} \bullet \mathrm{r}^{\prime}$ ethephon did not adversely affect flowering when applied at any time during the first seven weeks after the start of SD. At 1500 or $2500 \mathrm{mg}^{-1}$, ethephon applied at any time during the first five weeks after the start of SD maximized the number of vegetative buds and minimized the number of viable flower buds. When applied more than six weeks after SD began, ethephon did not promote the formation of vegetative axillary buds but did promote flower bud abortion.

\section{EFFECT OF MODIFIED ATMOSPHERE PACKAGING ON CARNATION}

A.J.Pertuit.Jr**and P.J. Verpano Departments of Horticulture and Food Science Clemson University, Clemson, SC 29634

Cut carnation (Dianthus caryophyllus) 'White Sim' flowers from Columbia (South America), nontreated or dipped for three seconds in water or $9.5 \mathrm{~g} / 1$ benlate (DuPont) or 3336 (Cleary), were placed in "orchid tubes" and remained in air or were packaged in barrier bags of air or $10 \% \mathrm{CO} 2 / 10 \% \mathrm{O} 2(80 \% \mathrm{~N} 2)$. Postharvest life (days) was recorded, and the $\mathrm{CO} 2, \mathrm{O} 2$, and $\mathrm{CH}_{2}=\mathrm{CH} 2$ concentrations within the bags were monitored with gas chromatographs. Controls, nonsealed and in air, did not differ in postharvest life, indicating no benefit from a fungicide dip $(\mathrm{P}=0.05)$. Botrytis was not observed in this test. Flowers sealed in bags did not differ in postharvest life $(\mathrm{P}=$ 0.05 ); however, when a single degree of freedom comparison was made ( $P R>F$ : 0.0001 ), their postharvest life was longer than controls ( 5.8 vs. 3.1 days). In bags, $\mathrm{CO} 2$ increased and $\mathrm{O} 2$ decreased over time, $\mathrm{CO} 2$ remaining higher and $\mathrm{O} 2$ lower with the $10 \% \mathrm{CO} 2 / 10 \% \mathrm{O} 2$ treatment. $\mathrm{CH} 2=\mathrm{CH} 2$ increased to $4 \mathrm{ppm}$ over 10 days, but ppm within bag treatments did not vary on any day $(P=0.05)$. 
DEBLOSSOMING IN EARLY SEASON AS IT AFFECTS YIELD

DISTRIBUTION OF JUNEBEARING STRAWBERRY IN A

SUBT ROPIC AL CLIM ATE GREENHOUSE

I. G. Rubeiz*, R. Y. Khoury and I. A. Al-Assir, Faculty of

A griculture, A merican University of Beirut, Beirut, Lebanon.

Blossom removal of "Douglas" strawberry for the first two weeks

of flowering , was studied as to its effect on fruit yield of plants

grown inside a greenhouse located in a subtropical climate.

Deblossoming resulted in a slightly lower early yleld than

undeblossomed plants. From the fourth till the ninth week of harvest,

deblossomed plants slightly outylelded undeblossomed plants. Yield

became similar among both treatments from the tenth week till the

last week of harvest (week 17). Weekly and total yields were not

significantly different ( $P>0.05$ ) among the treatments. Deblossomed

plants yielded $29.5 \mathrm{~kg} / 10 \mathrm{~m}^{2}$, whereas undeblossomed plants yielded

$28.2 \mathrm{~kg} / 10 \mathrm{~m}^{2}$, during the harvest period. Since these plants are grown for one season in the greenhouse, from November till June after which they are dug out, there will be no future carry over effect of deblossoming on these plants. Furthermore, the highest economical returns are from the first weeks of harvest, hence, any treatment which reduces early yield in return for a higher later yield, has to be weighed against the higher economical returns of the lower but earlier yield. 